DOI (Science of the Total Environment 2017): http://dx.doi.org/10.1016/j.scitotenv.2017.05.135

¿2017, Elsevier. Licensed under the Creative Commons Attribution-NonCommercialNoDerivatives 4.0 International http://creativecommons.org/about/downloads

(c) (†) $\ominus$ 


\title{
Riparian vegetation in the alpine connectome: Terrestrial- aquatic and terrestrial-terrestrial interactions
}

\author{
Dragos G. Zaharescu ${ }^{\mathrm{a}, \mathrm{b}\left({ }^{*}\right)}$, Antonio Palanca-Soler ${ }^{\mathrm{b}}$, Peter S. Hoodac ${ }^{\mathrm{c}}$, Catalin Tanase ${ }^{\mathrm{d}}$, Carmen I. \\ Burghelea $^{\mathrm{a}, \mathrm{b}}$, Richard N. Lester ${ }^{\mathrm{e}}$
}

\footnotetext{
${ }^{a}$ Biosphere-2, University of Arizona, Tucson, Arizona, USA.

${ }^{\mathrm{b}}$ Ecology and Animal Biology Department, University of Vigo, Vigo, Pontevedra, Spain

${ }^{c}$ School of Natural and Built Environments, Kingston University London, UK

${ }^{d}$ Faculty of Biology, Alexandru loan Cuza University, Iași, Romania

${ }^{\mathrm{e}}$ Formerly at Birmingham University Botanic Gardens, Birmingham, UK

Passed away in April 2006 in Birmingham, UK
}

*Corresponding author: D.G. Zaharescu: zaha_dragos@yahoo.com

A.Palanca-Soler: apalanca@uvigo.es

P.S. Hooda: p.hooda@kingston.ac.uk

C. Tanase: tanase@uaic.ro

C.I. Burghelea: bcarmen@email.arizona.edu

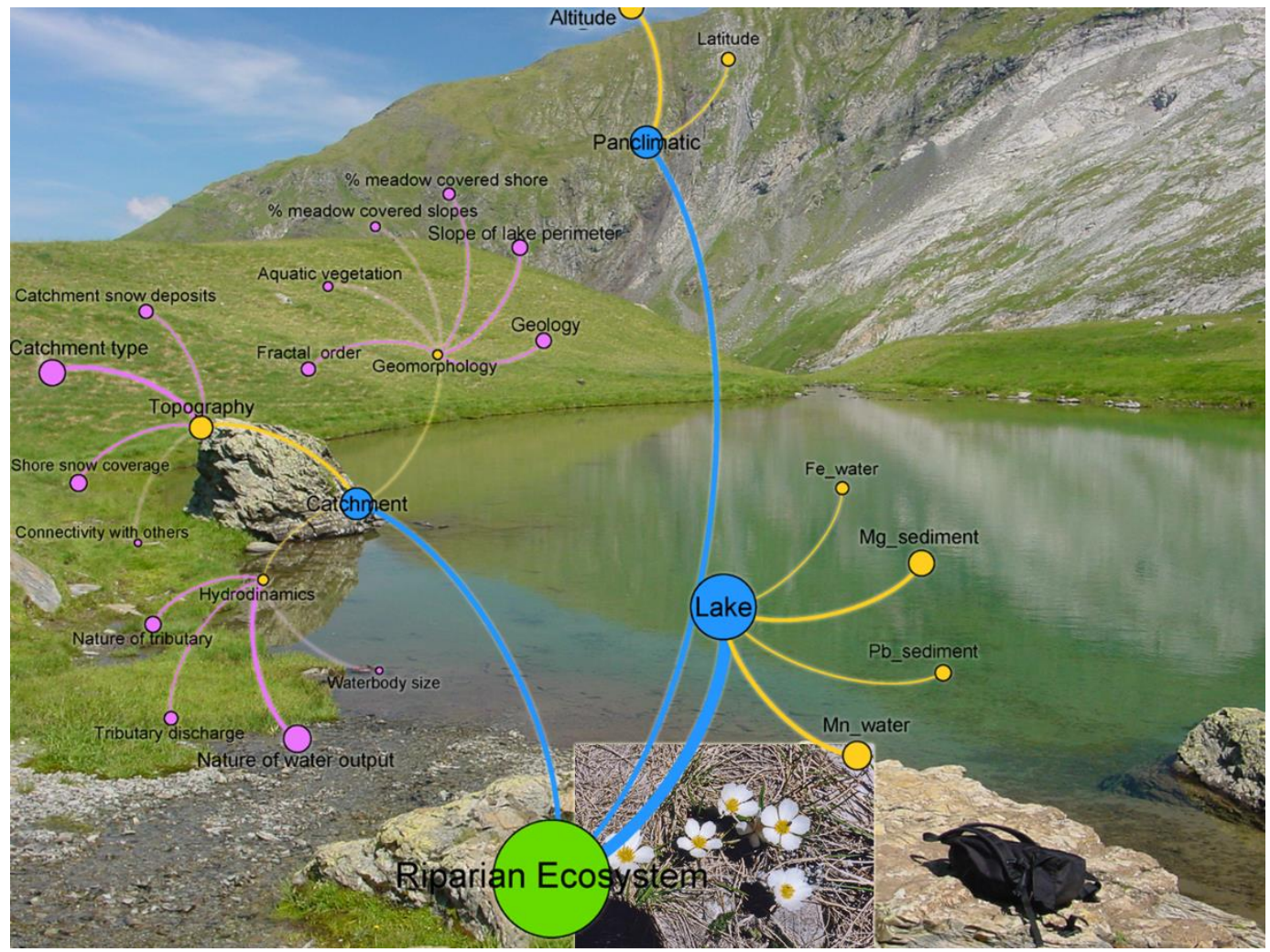

Graphical abstract: Riparian ecosystem of Lake Cardal (0.3ha, 2224m a.s.l) in the Pyrenees National Park (France), with a network diagram connecting ecotope features at a wide scale range, and Ranunculus pyrenaeus. Photos by Antonio Palanca - Soler and Richard N. Lester. 


\section{ABSTRACT}

Alpine regions are under increased attention worldwide for their critical role in early biogeochemical cycles, their high sensitivity to environmental change, and as repositories of natural resources of high quality. Their riparian ecosystems, at the interface between aquatic and terrestrial environments, play important geochemical functions in the watershed and are biodiversity hotspots, despite a harsh climate and topographic setting. With climate change rapidly affecting the alpine biome, we still lack a comprehensive understanding of the extent of interactions between riparian surface, lake and catchment environments.

A total of 189 glacial - origin lakes were surveyed in the Central Pyrenees to test how key elements of the lake and terrestrial environments interact at different scales to shape riparian plant composition. Secondly, we evaluated how underlying ecotope features drive the formation of natural communities potentially sensitive to environmental change and assessed their habitat distribution.

At the macroscale, vegetation composition responded to pan-climatic gradients altitude and latitude, which captured in a narrow geographic area the transition between large European climatic zones. Hydrodynamics was the main catchment-scale factor connecting riparian vegetation with major water fluxes, followed by topography and geomorphology. Lake sediment $\mathrm{Mg}$ and $\mathrm{Pb}$, and water $\mathrm{Mn}$ and Fe contents reflected local influences from mafic bedrock and soil water saturation. Community analysis identified four keystone ecosystems: (i) damp ecotone, (ii) snow bed-silicate bedrock, (iii) wet heath, and (iv) calcareous substrate. These communities and their connections with ecotope elements could be at risk from a number of environmental change factors including warmer seasons, snow line and lowland species advancement, increased nutrient/metal input and water level fluctuations. The results imply important natural terrestrial-aquatic linkages in the riparian environment at a wide range of scales, which could help better address further biomic impacts of environmental change.

Keywords: Alpine Lakes; Plant Composition; Ecotope; Catchment Heterogeneity; Fuzzy Set Ordination; Indicator Species Analysis. 


\section{INTRODUCTION}

Although they occupy $<24 \%$ of Earth's land surface, mountains contribute $>50 \%$ of total nutrients to the biosphere, as well as providing natural resources for more than half of the humanity (Price, 2004; Larsen et al. 2014). This is primarily due to an elevated and steep topography, and exposed geology, which create conditions for water precipitation and accumulation, and nutrient release through accelerated bedrock weathering (Larsen et al. 2014). The alpine biome, characterised by rough climate and topography, hosts ecosystems strongly connected to the underlying bedrock and is highly sensitive to small changes in external factors such as climate and atmospheric chemistry (Williamson et al., 2009; Storkey et el. 2015).

The vast majority of low-laying landforms in the present mountain landscape are the legacy of Pleistocene glaciation (Thornbury, 1969). This produced $>50,000$ remote lakes in Europe alone (Kernan et al., 2009), and > 4000 in the Pyrenees (Castillo-Jurado, 1992). Their riparian surfaces, at the interface between terrestrial and aquatic environments, have a major role in modulating the fluxes of water and nutrients between catchment and lake ecosystems. These surfaces host a rich biodiversity compared to the surrounding landscapes (Gregory et al., 1991, Kernan et al., 2009), and are well extended (> 797 km of shoreline in the Pyrenees alone; Castillo-Jurado, 1992).

Interactions between vegetation, bedrock features, including morphology and geochemistry, and climate determine species distribution patterns in concert with environmental gradients (Austin and Smith, 1989; Hengeveld, 1990). Baroni-Urbani et al. (1978) introduced the term chorotype to define a pool of species with overlapping distributions. Fattorini (2015) revisited the concept and further classified the chorotype into global (for worldwide distribution) and regional. A regional chorotype is assumed to occupy a small geographic area, often used as study area in a biome, and it can present various degrees of continuity.

Stress related factors such as low temperature, snow and ice abrasion, high UV radiation and water-level fluctuations, overlapping to a variable geology and topography have the 
potential to increase fragmentation in alpine riparian populations and result in island communities tightly connected to their local environment. Waterbody isolation could also limit gene flow among such communities. Restrictive influence on plant distribution has been shown in localized areas, due to climate factors such as the type and intensity of precipitation, daily temperature, the frequency of freezing events and their duration (Keller et al., 2005), as well as slope orientation and altitude (Baker, 1989).

The influence of riparian vegetation on catchment chemistry can be diverse. On one hand, the production of organic acids and $\mathrm{CO}_{2}$ by plant roots and microbial communities in the rhizosphere can modulate the fluxes of nutrients into a lake by enhancing bedrock weathering (Burghelea et al., 2015). On the other hand, litter degradation in the water-saturated environment can increment the export of dissolved organic carbon, which chelates major biogenic cations (Mg, Ca and Si), further mobilizing them (Zakharova et al., 2007). Metal-rich mafic and ultramafic deposits, as well as mining of metal-rich ores have been reported in this part of the Pyrenees, and tainting of stream water with $\mathrm{Pb}$ and $\mathrm{Cr}$ has also been described (Kilzi et al., 2016; Point et al., 2007). This mineralogy could imprint a strong effect on vegetation composition and its evolution through time, including by incrementing the endemism level (Galey et al., 2017). This then raises the question of whether the contrasting geology and the presence of mafic deposits in the Pyrenees can be reflected in the composition of its riparian ecosystems.

Anthropogenic climate change, particularly changes in precipitation, air temperature, freezing line, temporary and permanent snow cover, can greatly influence the thermodynamics and geochemistry of high altitude waterbodies (Thompson et al., 2005; Parker et al., 2008; Zaharescu et al. 2016a), and consequently their ecosystems (Khamis et al., 2014). With many mountain species already in dwindling numbers (Kreyling et al., 2014; Buma et al. 2016), it becomes critically important to better define the breadth and strength of their natural connectivity with the sustaining physicochemical template (ecotope) at both, local and the broader landscape scales, before this is irreversibly severed. We will use the term connectome (first introduced by Sporns, 2006, and Hagmann, 2005 in neurosciences) to denote the 
functional linkages between a riparian ecosystem and the wider environment, as it offers a more natural way to understand ecosystem interactions.

Research exploring the connection between riparian ecosystem and its physical template (ecotope) at different scales is rare. It has largely been conducted at low altitudes, e.g. by focusing on how local scale alterations in hydrological and habitat disturbance affect riparian communities (Merritt et al., 2010). Related work in mountain catchments has quantified the ability of bedrock geomorphology to predict the type of riparian plant communities and species abundances at different scales (Engelhardt et al., 2015). This study found that catchment-scale characteristics, including bedrock type, drainage area, and water discharge are the best predictors of riparian species composition in mountain streams. More recently, we proposed a conceptualized model of alpine lake ecotopes (Zaharescu et al., 2016b), and assessed their influence on zoobenthic communities (Zaharescu et al., 2016c). Catchment-scale hydrodynamics was the largest driver of a lake ecotope, while topography (controlling catchment type, snow coverage, and inter-lake connectivity) was the most influential in zoobenthic community formation. Locally, riparian plant assemblages also seemed to affect the zoobenthos composition, diversity and richness, likely through their nutrient and habitat support (Zaharescu et al., 2016b; Zaharescu et al., 2016c). Here we further explore how major ecotope structures interact to shape the riparian plant communities at several scales, using as a model an alpine region of limited human impact, i.e. Pyrenees National Park.

The motivation behind this study was to attain a mechanistic understanding of highelevation riparian ecosystem development in relationship with its ecotope, and its potential response to environmental change. The objectives were: (i) to assess the cross-scale linkages between ecosystem, lake and catchment environments, and evaluate their strength; (ii) to identify keystone plant communities and lakes, which could be potential sensors of environmental change, and (iii) to evaluate their preference to landscape gradients. We postulate that the extreme geoclimatic setting of the alpine biome determines a strong riparian connection to local lake variables, and to a lesser extent to larger scale factors. This, in turn, creates local indicator communities, which may be highly susceptible to environmental change. 
The location of the Pyrenees at the intersection of four large biogeographical regions, i.e. Atlantic, Continental, Mediterranean and Alpine, makes them richer in biodiversity compared to similar areas, such as the Alps $( \pm 11.8 \%$ endemic plant species in the Pyrenees; Gómez et al., 2003), and highly susceptible to climate change. They are, therefore, an excellent candidate for this study.

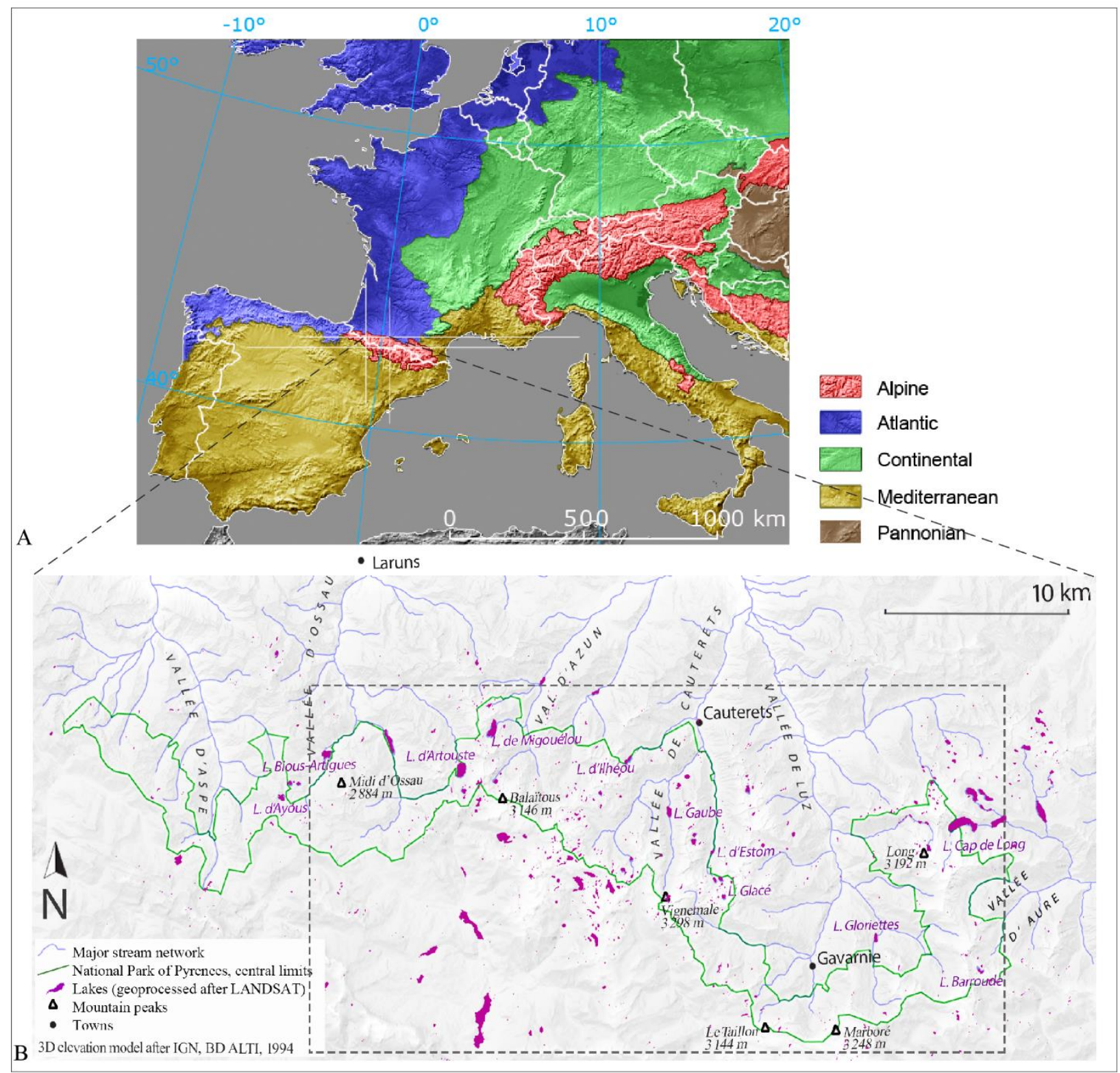

Figure 1 Biogeographical regions of W Europe (A, after EEA, 2001), with the location study area (B) in the axial part of Pyrenees National Park, France. Surveyed lakes, enclosed by a dash-line box, were within the park boundaries.

\section{METHODS}




\subsection{The area}

The Pyrenees are a relatively young mountain chain in SW Europe and a natural barrier between Spain and France. Their topography was carved mostly during the last glaciation 11,000 years ago, which left an abundance of lakes and ponds in cirques and valleys. The lakes, at different ecological succession stages, are more abundant on the steeper French side, which generally receives more precipitation.

The study area extended from - $0^{\circ} 37^{\prime} 35^{\prime \prime}$ to $0^{\circ} 08^{\prime} 19^{\prime \prime} \mathrm{E}$ and $42^{\circ} 43^{\prime} 25^{\prime \prime}$ to $42^{\circ} 49^{\prime} 55^{\prime \prime} \mathrm{N}$ in the axial region of the Pyrenees National Park, France (Fig. 1). The geology is dominated by granitic batholiths, surrounded by old metamorphic and sedimentary materials, including slates, schist, and limestone. The hydrology is broadly shaped by Atlantic influences, which feed $>400$ lakes and ponds in the park. A great number of lakes are drained by temporary torrents and permanent streams, which converge into major valleys, though isolated waterbodies and karstic systems are not rare. The valleys generally follow an $\mathrm{S}-\mathrm{N}$ direction. Some of the big lakes at lower altitudes were transformed into reservoirs and are used for hydropower and as freshwater reserves of high quality.

\subsection{Sampling strategy}

Three expeditions were conducted in July of 2000, 2001 and 2002 to sample the majority $(n=$ 189) of lakes and ponds from the axial region of the park, from an altitudinal range of 1161 to $2747 \mathrm{~m}$ a.s.I. (Table S1). Due to the difficulty of sampling at high altitudes over extended periods (including > 6 winter months, extreme weather and steep topography), and to capture a comparable phenology, sampling was designed to cover the blooming summer phenology.

Each lake was characterised according to riparian vegetation composition and a range of catchment physical and chemical attributes (Table S2). Ocular identification of species in the perimeter of each waterbody was recorded in the field using Grey-Wilson and Blamey (1979), Fitter et al. (1984) and García-Rollán (1985) keys. Hard to identify plants were collected and transported in a vasculum to the laboratory for identification. They were thereupon identified using Flora Europaea (available online at http://rbg-web2.rbge.org.uk/FE/fe .html). 
At each location, hydrological (tributary discharge, nature and size of tributary and output), geomorphological (bedrock geology, \% slope of lake perimeter, fractal development level, \% shore and near-catchment slope covered by meadow and aquatic vegetation) and topographical (catchment type, catchment and shore snow coverage and connectivity with other lakes) attributes were visually inspected and scored according to dominant features (Table S2). Geolocation, i.e. altitude, latitude, and longitude was recorded at each lake using a portable GPS device. Fractal shore development was estimated visually on a scale from 1 (simple shoreline) to 2 (simple intrusions), 3 (branched intrusions) and 4 ( $2^{\text {nd }}$ order branched intrusions). It is assumed to roughly reflect shoreline development during a lake's ecological succession stages.

To test for relationships between lake chemistry and riparian vegetation composition, < $3 \mathrm{~cm}$ depth littoral sediments and water $\pm 5 \mathrm{~m}$ off the littoral (for small waterbodies, the distance was less) were sampled using a polyethylene trowel. The sediments comprised fragmented rocks, coarse sands, and fine silts. As the chemical composition of the fine sediment fraction is the most likely to relate to riparian vegetation, i.e. they are either source or sink of the bioavailable element fraction), sampling deliberately targeted this fraction. To assure sample homogeneity, at each lake the sample comprised roughly 5 randomly selected subsamples. All sediment and water samples were kept at $<4^{\circ} \mathrm{C}$ until laboratory analysis.

Water $\mathrm{pH}$ and conductivity were measured on site, at the surface and bottom of the lake from samples taken with a Teflon bottom water sampler. Hach HQ40d portable $\mathrm{pH}$ and conductivity probes (IntelliCAL PHC201, accuracy $\pm 0.002 \mathrm{pH}$ and IntelliCAL CDC401, accuracy \pm $0.5 \%$ from $1 \mu \mathrm{S} / \mathrm{cm}-200 \mathrm{mS} / \mathrm{cm}$ ) were used.

\subsection{Sample preparation for major and trace element analysis}

The sediment samples were dried at $40{ }^{\circ} \mathrm{C}$ for two days and sieved through a $100 \mu \mathrm{m}$ sieve. Trace and major element contents were characterised by X-ray fluorescence spectrometry (XRF). A $5 \mathrm{~g}$ portion of the sample was prepared as lithium tetraborate melt for the determination of major ( $\mathrm{Na}, \mathrm{Mg}, \mathrm{Al}, \mathrm{Si}, \mathrm{P}, \mathrm{S}, \mathrm{Cl}, \mathrm{K}, \mathrm{Ca}, \mathrm{Ti}$, and $\mathrm{Fe}$ ) and trace ( $\mathrm{V}, \mathrm{Cr}, \mathrm{Mn}, \mathrm{Co}, \mathrm{Ni}$, $\mathrm{Cu}, \mathrm{Zn}, \mathrm{As}, \mathrm{Rb}, \mathrm{Sr}, \mathrm{Ba}$ and $\mathrm{Pb}$ ) elements. Results are expressed in $\%$ mass-mass and $\mathrm{mg} \mathrm{kg}^{-1}$, respectively for major and trace elements. Fusions were performed in $\mathrm{Pt}-\mathrm{Au}$ crucibles. 
Calibration and quality control analyses were carried out using replicated certified reference materials from National Research Council of Canada, NRCC (SO-3, SO-4, HISS-1, MESS-3 and PACS-2, soils and sediments) and from South Africa Bureau of Standards, SACCRM (SARM 52, stream sediment). Additionally, a given sample was analyzed several times during the analysis run. The analysis was highly reliable, with the recovery figures for the reference materials being within an acceptable range for all major elements ( $\pm 10 \%)$. Percent coefficient of variation (\% CV) between replicates was $<5 \%$ and \% relative standard deviation, RSD ( $1 \sigma)$ between measurements of the same sample $<2 \%$.

Total $\mathrm{C}$ and $\mathrm{N}$ contents were simultaneously determined by flash combusting $5 \mathrm{mg}$ dried sediments in a Carlo Erba 1108 elemental analyzer following standard operating procedure (Verardo et al., 1990).

Water samples were prepared for analysis by filtering through $0.45 \mu \mathrm{m}$ cellulose nitrate membrane followed by acidification to $2 \%$ with ultrapure Merck nitric acid. The acidified samples were analyzed for $\mathrm{Li}, \mathrm{B}, \mathrm{Na}, \mathrm{Mg}, \mathrm{Al}, \mathrm{K}, \mathrm{Ca}, \mathrm{Mn}, \mathrm{Fe}, \mathrm{Ni}, \mathrm{Cu}, \mathrm{Ga}, \mathrm{Se}, \mathrm{Sr}, \mathrm{Ba}, \mathrm{Rb}$ and Pb by inductively coupled plasma - optical emission spectrometer (ICP-OES) using standard ICPMS/OES operating conditions. The results are expressed in $\mathrm{mg} \mathrm{L}^{-1}$. The analysis, following standard procedures and QA/QC protocols, were performed at the University of Vigo's Centre for Scientific and Technological Support (CACTI).

\subsection{Statistical procedures}

A diagram of statistical analysis steps is presented in Fig. 2. 


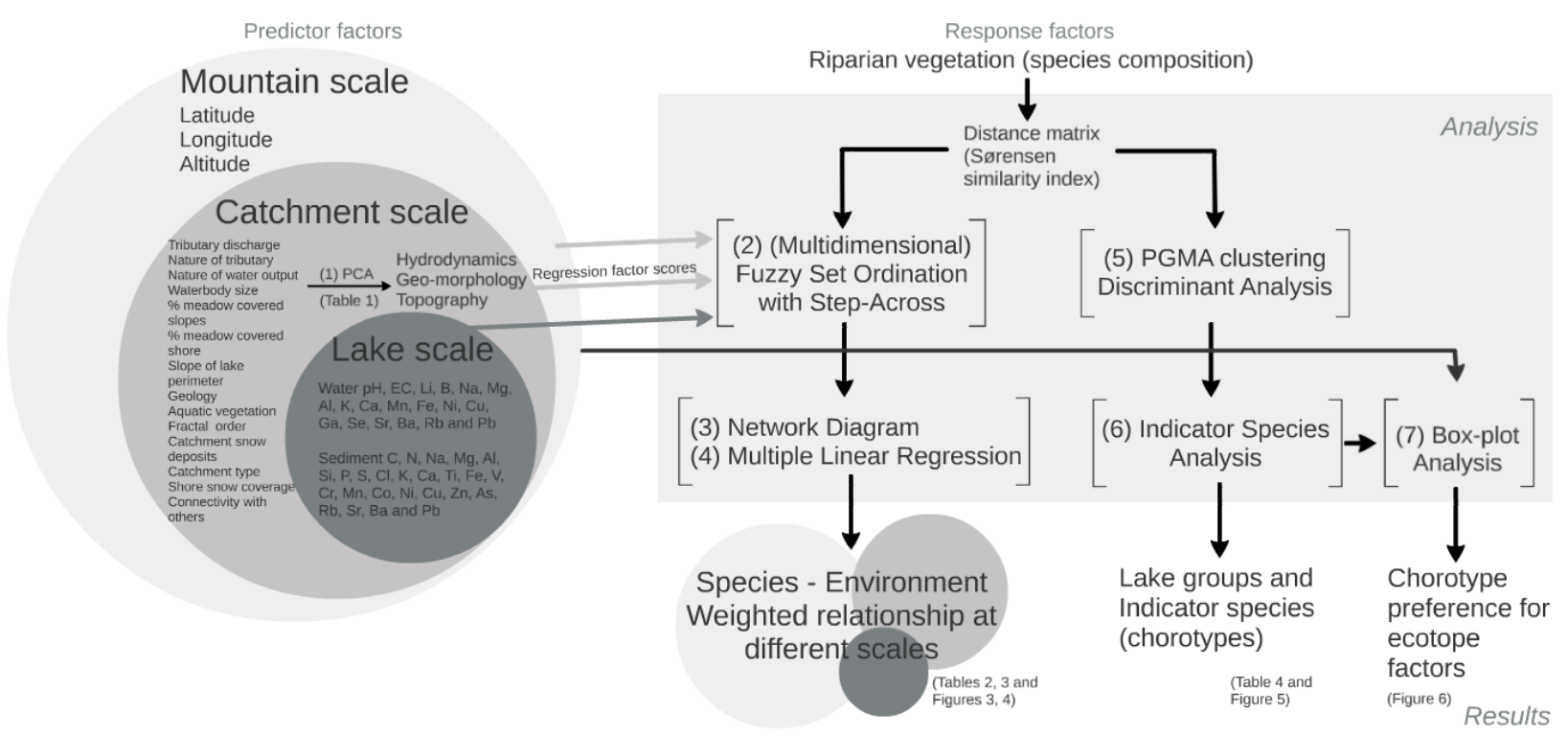

Figure 2 Data analysis flow chart displaying input variables collected at different scales (top and left), analysis steps (central box) and their outcomes (bottom).

Table 1 Association of lake catchment variables into three composite factors. Variables are listed in order of their correlation with the principal components (PC). Highest correlation of a variable with any of the components is in bold. PC1 was interpreted as hydrodynamics; PC2, geo-morphology, and PC3, topography formation. Variable values are in Table $\mathbf{S} 2$.

\begin{tabular}{lrrr}
\hline & \multicolumn{3}{c}{ Principal component } \\
\cline { 2 - 4 } & PC 1 & PC 2 & PC 3 \\
\hline Tributary discharge & $\mathbf{0 . 9 2}$ & 0.04 & 0.02 \\
Nature of tributary & $\mathbf{0 . 9 0}$ & 0.02 & 0.01 \\
Nature of water output & $\mathbf{0 . 8 7}$ & -0.17 & 0.07 \\
Waterbody size & $\mathbf{0 . 5 2}$ & -0.38 & 0.05 \\
\% meadow covered slopes & -0.07 & $\mathbf{0 . 7 2}$ & -0.37 \\
\% meadow covered shore & 0.21 & $\mathbf{0 . 6 8}$ & -0.24 \\
Slope of lake perimeter & 0.30 & $-\mathbf{0 . 6 7}$ & -0.03 \\
Geology & -0.23 & $\mathbf{0 . 6 0}$ & 0.07 \\
Aquatic vegetation & -0.16 & $\mathbf{0 . 5 8}$ & -0.22 \\
Fractal order & 0.07 & $\mathbf{0 . 5 0}$ & 0.08 \\
Catchment snow deposits & 0.09 & -0.10 & $\mathbf{0 . 8 6}$ \\
Catchment type & 0.05 & 0.07 & $\mathbf{0 . 7 9}$ \\
Shore snow coverage & -0.11 & -0.11 & $\mathbf{0 . 7 5}$ \\
Connectivity with others & 0.39 & -0.36 & $\mathbf{0 . 5 2}$ \\
\hline Total Eigenvalue (rotated) & 3.07 & 2.69 & 2.46 \\
\% of variance explained & 21.96 & 19.24 & 17.59 \\
Cumulative \% & 21.96 & 41.20 & $\mathbf{5 8 . 7 9}$ \\
\hline Rotation method Varimax with Kaiser normalization
\end{tabular}

\subsubsection{Principal component analysis to summarize ecotope factors}


Principal component analysis (PCA) was used to reduce the multiple catchment-scale variables to a limited number of composite factors (principal components, PCs), which represent major ecotope properties being investigated, according to the procedure developed in Zaharescu et al. 2016b (Table 1). The regression factor scores of the principal components (extracted after an orthogonal Varimax rotation) were then used as explanatory variables in the further analysis of vegetation data. This analysis was performed in PASW (currently IBM- SPSS) statistical package for Windows.

\subsection{2 (Multidimensional) Fuzzy Set Ordination to quantify riparian drivers}

To understand the potential effects of catchment gradients on vegetation species composition we used Fuzzy Set Ordination (FSO) followed by a forward - stepwise multidimensional FSO (MFSO), both run on a distance matrix of species incidence data.

Introduced by Roberts (1986), FSO is a more natural alternative to constrained ordination methods, e.g. CCA and RDA. Compared to the classical theory in linear algebra, where cases are either in or out of a given set (0 or 1), in FSO cases are assigned partial membership (fuzzy) values ranging from 0 to 1 that denote their degree of membership in a set (Roberts, 2008). Likewise, species responses to environmental factors are generally not limited to a certain function; they can be, for example, nonlinear or discontinuous. FSO, therefore, is a generalized technique (Roberts, 1986), which overcomes this problem and includes the types of ordination that ecologists are more familiar with, such as gradient analysis (Whittaker, 1967) and environmental scalars ordination (Loucks, 1962). Thus, in fuzzy logic applications, the results can facilitate the expression of natural rules and processes.

First, a distance matrix of species incidence was calculated. For the binary data (presence-absence) considered herein, we used Sørensen similarity index, as suggested by Boyce and Ellison (2001). This gave a measure of similarity between sites based solely on species composition. This was followed by one-dimensional FSO, taking distance matrices of species as response variables and the environmental variables as explanatory variables. FSO also requires that the environmental variables be as much uncorrelated as possible (Boyce, 2008). A number of landscape variables showed a strong correlation. Their summarized version, i.e. the PC regression factor scores from prior PCA (Table 1), were therefore used as 
explanatory variables in FSO. By default, the principal components of PCA computed with an orthogonal (e.g. Varimax) rotation are uncorrelated, therefore, suitable for this approach.

To remove potential covariance between factors and better quantify the effect size of each factor on riparian vegetation, a multidimensional FSO (MFSO) was run on factors with correlation coefficient with species distance matrix $(r)>0.3(p<0.05)$. This allowed a more accurate multidimensional interpretability of the results. Statistically, MFSO first performs an FSO on the variable accounting for most of the variation. Then, the residuals from that fuzzy ordination are used with the next most important variable, and the process is repeated until no more variables are left. Therefore, unlike the widespread ordination methods used in ecology, e.g. Principal Component Analysis (PCA), Canonical Correspondence Analysis (CCA) and distance-based redundancy analysis (DB-RDA), in MFSO each variable selected by the model can be considered as an independent axis, and only the fraction of axis membership values which is uncorrelated with previous axes is included into the model (Roberts, 2009a). Moreover, MFSO is expected to perform better than other unconstrained ordination methods on more complex datasets, as it is less sensitive to rare species and noise in environmental factors (Roberts, 2009a) - therefore better reflecting the average community behavior.

The effect magnitude of each environment variable on plant species composition was assessed visually by the relative scatter attributable to that variable, and numerically by its increment in the correlation coefficient. Similar to regression modeling, if an axis is influential in determining the distribution of vegetation, then one should be able to predict the values of that variable based on species composition (Roberts, 2009b). A "step-across" function was used on MFSO results, to improve the ordination with high beta diversity, i.e. for sites with no species in common (Boyce and Ellison, 2001).

The significance of the matrix correlation coefficient between environmental variables and species composition was established by permuting the rows and columns of one of the matrices 1000 times in both, FSO and MFSO, recalculating the correlation coefficient and comparing the observed matrix correlation coefficient with the distribution of values obtained via permutation. 
FSO and MFSO were computed with FSO (Roberts, 2007a) and LabDSV (Roberts, 2007b) packages, while the step-across function was computed with VEGAN package (Oksanen et al., 2009), R statistical language and environment.

\subsubsection{Network diagram}

A conceptual diagram summarizing the linkages between riparian vegetation and surrounding landscape elements, and their magnitude of influence was assembled in the open-source visualization tool Gephi 0.9.1 (https://gephi.org; Bastian et. al. 2009) using Yifan Hu layout. Gephi is a highly interactive visualization platform capable of displaying the relationships between nodes of a semantic network based on object abundances or objects weight. It allows users to intuitively discover patterns, isolate network structures, and singularities, and derive hypotheses in social and biological networks analyses. We used the independent (incremental) $r$ values derived by MFSO as variable weights. Likewise, a multiple regression with Akaike Information Criterion model selection (Automatic Linear Modelling option in IBM-SPSS) provided the magnitude of influence each landscape variable had in the composite landscape factors previously summarized by PCA.

\subsubsection{Indicator community analysis}

The riparian vegetation composition (incidence data) was analyzed for species association into chorotypes, i.e. species with significant co-occurrence patterns, using cluster analysis. First, the lakes were grouped on the basis of shared species. A Pair-Group clustering Method using the Arithmetic Averages (PGMA), flexible linkage parameter, beta $=-0.2$, was computed using the Sørensen distance matrix of species incidence. This allowed selecting the most appropriate clustering for dendrogram nodes cut.

The selected clusters were subsequently assigned code numbers into a new categorical variable. This variable was used as a grouping variable in Indicator Species Analysis (Dufrene and Legendre, 1997), to determine plant species with significant affinity to the lake categories, i.e. species of similar ecological preferences. An indicator community comprises species that are most characteristic in the riparian zone of lakes of that type. The higher the indicator value is, the greater is the species affinity to a lake type. When clustering membership of species 
could not be established statistically, they were assumed to follow continuum distributions (Báez et al., 2005).

Furthermore, the selectivity of the resulting vegetation communities to different ecotope features was tested by box-plotting them against environmental gradients. Sørensen similarity matrix was computed with ADE4 (dist.binary function; Thioulouse et al., 1997), cluster and boxplot analyses with CLUSTER (agnes and boxplot functions, respectively; Kaufman and Rousseeuw, 1990), Discriminant Analysis with FPC (plotcluster function; Hennig, 2005) and Indicator Species Analysis with LabDSV (indval function; Dufrene and Legendre, 1997) packages for R statistical language (R Core Development Team, 2005); available online at http://cran.rproject.org/.

\section{RESULTS AND DISCUSSION}

\subsection{Major catchment-scalle variates}

Interactions between the lake, catchment, and larger geographical gradients create major environmental forces, which shape the development of ecosystems at the land-water interface. PCA extracted three principal components, together accounting for more than $58 \%$ of the total variance in lake' catchment characteristics (Table 1).

The first component, PC1, is interpreted as hydrodynamics and is formed by tributary nature and discharge, type of water output and waterbody size (Table 1). The second component, PC2, characterises the major bedrock geo-morphology, i.e. geology, shore sloping, $\%$ of slope and shore covered by meadow, fractal order (riparian development) and the presence of aquatic vegetation. The third PC, PC3, represents topography influence, i.e. catchment type, visible connectivity with other lakes, and catchment and shore snow deposits. The three composite factors were, therefore regarded as major landscape drivers, and are expected to influence riparian the ecosystem development. 


\subsection{Influence of lake, catchment, and pan-climatic drivers on}

\section{vegetation composition}

A single-dimensional FSO, used as an initial step in evaluating the linkages between large-scale, catchment-scale and lake scale variables, and vegetation composition (first objective in this study), clearly identified altitude to exert the largest influence (Table 2). This was followed by local-scale water $\mathrm{Mn}$ and $\mathrm{Fe}$, and sediment $\mathrm{Mg}$ contents, large horizontal gradients latitude and longitude, and catchment-scale variables topography formation and hydrodynamics (Table 2). The effect size of each of the factors showing a correlation coefficient with vegetation composition $r>0.3(p<0.05)$, were introduced in an MFSO model (to remove potential covariation) and discussed in the following sections.

Table 2 One-dimensional fuzzy relationships between riparian vegetation species composition and environmental factors in the Pyrenees lakes. Factor superscripts: (a) macroscale, (b) catchment-scale (Table 1), (c) lake-scale sediment, and (d) lake-scale water variables. Correlations between factors and apparent factors predicted by vegetation are listed in descending order for each variable group (on different grey shades). Factors with correlations $>0.3$ (in bold) were retained for further MFSO analysis. $P$ represents the probability after 1000 permutations

\begin{tabular}{|c|c|c|c|c|c|}
\hline Variable & $r$ (Pearson) & $P$ & Variable (continued) & $r$ (Pearson) & $P$ \\
\hline${ }^{\mathrm{a}}$ Altitude & 0.855 & 0.001 & ${ }^{\mathrm{c}} \mathrm{Sr}$ & -0.005 & 0.545 \\
\hline a Latitude & 0.695 & 0.001 & ${ }^{\mathrm{c}} \mathrm{Na}$ & -0.020 & 0.439 \\
\hline${ }^{\mathrm{a}}$ Longitude & 0.636 & 0.001 & ${ }^{\mathrm{C}} \mathrm{Ti}$ & -0.107 & 0.540 \\
\hline${ }^{\mathrm{b}}$ Topography (PC3) & 0.644 & 0.001 & ${ }^{\mathrm{c}} \mathrm{Rb}$ & -0.164 & 0.624 \\
\hline${ }^{\mathrm{b}}$ Geo-morphology (PC2) & 0.603 & 0.001 & ${ }^{\mathrm{c}} \mathrm{Al}$ & -0.443 & 0.900 \\
\hline${ }^{\mathrm{b}}$ Hydrodynamics (PC1) & 0.442 & 0.001 & ${ }^{d} \mathrm{Mn}$ & 0.751 & 0.001 \\
\hline${ }^{\mathrm{c}} \mathrm{Mg}$ & 0.712 & 0.001 & ${ }^{d} \mathrm{Fe}$ & 0.730 & 0.001 \\
\hline${ }^{\mathrm{c}} \mathrm{Pb}$ & 0.515 & 0.003 & ${ }^{d}$ Conductivity (surface) & 0.584 & 0.001 \\
\hline${ }^{\mathrm{c}} \mathrm{Ca}$ & 0.510 & 0.004 & ${ }^{d}$ Conductivity (bottom) & 0.545 & 0.001 \\
\hline${ }^{\circ} \mathrm{Cu}$ & 0.501 & 0.007 & ${ }^{\mathrm{d}} \mathrm{Al}$ & 0.531 & 0.014 \\
\hline${ }^{\mathrm{c}} \mathrm{Co}$ & 0.497 & 0.006 & ${ }^{d} \mathrm{Cu}$ & 0.465 & 0.009 \\
\hline${ }^{\mathrm{c}} \mathrm{Ba}$ & 0.484 & 0.007 & ${ }^{\mathrm{d}} \mathrm{pH}$ (bottom) & 0.307 & 0.002 \\
\hline${ }^{\mathrm{C} N \mathrm{Ni}}$ & 0.432 & 0.018 & ${ }^{\mathrm{d}} \mathrm{pH}($ surface $)$ & 0.257 & 0.002 \\
\hline${ }^{\mathrm{C}} \mathrm{Mn}$ & 0.405 & 0.024 & ${ }^{d} K$ & 0.254 & 0.108 \\
\hline${ }^{\mathrm{c}} \mathrm{Fe}$ & 0.362 & 0.037 & ${ }^{\mathrm{d}} \mathrm{Na}$ & 0.204 & 0.170 \\
\hline${ }^{\mathrm{c}} \mathrm{Zn}$ & 0.361 & 0.033 & ${ }^{d} B$ & 0.177 & 0.089 \\
\hline${ }^{\mathrm{C}} \mathrm{C}$ & 0.351 & 0.032 & ${ }^{d} \mathrm{~Pb}$ & 0.130 & 0.272 \\
\hline${ }^{\mathrm{c}} \mathrm{Si}$ & 0.337 & 0.046 & ${ }^{d} \mathrm{Ba}$ & 0.108 & 0.248 \\
\hline${ }^{\mathrm{c}} \mathrm{N}$ & 0.324 & 0.036 & ${ }^{d} S r$ & 0.088 & 0.293 \\
\hline${ }^{\mathrm{C}} \mathrm{Cr}$ & 0.309 & 0.069 & ${ }^{d} \mathrm{Se}$ & 0.057 & 0.340 \\
\hline
\end{tabular}




\begin{tabular}{|c|c|c|c|c|c|}
\hline${ }^{c} \mathrm{~V}$ & 0.210 & 0.130 & ${ }^{\mathrm{d}} \mathrm{Ni}$ & -0.010 & 0.482 \\
\hline${ }^{\circ} \mathrm{C} / \mathrm{N}$ & 0.114 & 0.145 & ${ }^{\mathrm{d}} \mathrm{Ga}$ & -0.020 & 0.445 \\
\hline 'S & 0.112 & 0.249 & ${ }^{d} \mathrm{Li}$ & -0.030 & 0.462 \\
\hline${ }^{\mathrm{c}}$ As & 0.110 & 0.298 & ${ }^{d} \mathrm{Mg}$ & -0.101 & 0.590 \\
\hline${ }^{c} K$ & 0.029 & 0.342 & ${ }^{\mathrm{d}} \mathrm{Ca}$ & -0.234 & 0.746 \\
\hline${ }^{c} \mathrm{P}$ & 0.013 & 0.394 & ${ }^{\mathrm{d}} \mathrm{Rb}$ & -0.350 & 0.841 \\
\hline${ }^{\mathrm{c}} \mathrm{Cl}$ & -0.001 & 0.418 & & & \\
\hline
\end{tabular}

\subsubsection{Large vertical and horizontal gradients}

Table 3 and Fig. 3a show the environmental factors in order of their independent correlation with the apparent factors predicted by vegetation composition. A two-axes solution resulted from MFSO, with altitude and latitude reliably predicting riparian plant composition (cumulative $r=0.65)$. Altitude, the most influential, is a classical vertical driver of ecosystem succession along the alpine climate gradient. The latitudinal variability in the study area (the secondly most important in the model) is relatively narrow. However, its location under four major biogeographical influences, namely Atlantic and Continental from the $\mathrm{N}$ and NW, Mediterranean

Table 3 Independent effect of a geoposition, ${ }^{b}$ catchment, ${ }^{c}$ sediment and ${ }^{d}$ water chemistry factors on riparian vegetation composition, as given by MFSO. Figures for geoposition, catchment and water characteristics resulted from MFSO with step-across function. $\gamma$ (gamma) $=$ a vector of the independent variance fraction of a factor (MFSO axis). Factors with the highest independent influence in the model, in bold, are listed in order of their weight, for each variable group (highlighted by different grey shades).

\begin{tabular}{|c|c|c|c|c|}
\hline Axis & $\begin{array}{r}\text { Cumulative } \\
r\end{array}$ & $\begin{array}{r}\text { Increment } \\
r\end{array}$ & $P$-value & $\gamma$ \\
\hline${ }^{\mathrm{a}}$ Altitude & 0.46 & 0.46 & 0.002 & 1.00 \\
\hline${ }^{\mathrm{a}}$ Latitude & 0.65 & 0.19 & 0.001 & 0.97 \\
\hline${ }^{\mathrm{a}}$ Longitude & 0.66 & 0.01 & 0.740 & 0.06 \\
\hline${ }^{\mathrm{b}}$ Topography (PC3) & 0.43 & 0.43 & 0.026 & 1.00 \\
\hline${ }^{\mathrm{b}}$ Geo-morphology (PC2) & 0.52 & 0.09 & 0.325 & 0.54 \\
\hline${ }^{\mathrm{b}}$ Hydrodynamics (PC1) & 0.64 & 0.12 & 0.001 & 0.97 \\
\hline${ }^{c} \mathrm{Mg}$ & 0.49 & 0.49 & 0.270 & 1.00 \\
\hline${ }^{\mathrm{c}} \mathrm{Pb}$ & 0.74 & 0.25 & 0.044 & 0.49 \\
\hline${ }^{\mathrm{C}} \mathrm{Ca}$ & 0.74 & 0.01 & 0.057 & 0.09 \\
\hline${ }^{\mathrm{c}} \mathrm{Cu}$ & 0.75 & 0.01 & 0.035 & 0.05 \\
\hline${ }^{\mathrm{c}} \mathrm{Co}$ & 0.76 & 0.01 & 0.025 & 0.05 \\
\hline${ }^{\mathrm{c}} \mathrm{Ba}$ & 0.75 & -0.01 & 0.142 & 0.06 \\
\hline${ }^{c} \mathrm{Ni}$ & 0.75 & -0.004 & 0.157 & 0.02 \\
\hline${ }^{\mathrm{c}} \mathrm{Mn}$ & 0.75 & -0.001 & 0.135 & 0.02 \\
\hline${ }^{\mathrm{c}} \mathrm{Fe}$ & 0.75 & 0.002 & 0.096 & 0.02 \\
\hline${ }^{c} \mathrm{Zn}$ & 0.75 & -0.001 & 0.118 & 0.01 \\
\hline${ }^{\mathrm{C}} \mathrm{C}$ & 0.74 & -0.01 & 0.334 & 0.09 \\
\hline${ }^{\mathrm{c}} \mathrm{Si}$ & 0.74 & 0.00 & 0.180 & 0.004 \\
\hline
\end{tabular}


DOI (Science of the Total Environment 2017): http://dx.doi.org/10.1016/j.scitotenv.2017.05.135

\begin{tabular}{|c|c|c|c|c|}
\hline${ }^{c} N$ & 0.74 & 0.00 & 0.164 & 0.01 \\
\hline${ }^{\mathrm{d}} \mathrm{Mn}$ & 0.56 & 0.56 & 0.281 & 1.00 \\
\hline${ }^{d} \mathrm{Fe}$ & 0.73 & 0.17 & 0.384 & 0.22 \\
\hline${ }^{\mathrm{d} C}$ Conductivity & 0.71 & -0.03 & 0.406 & 0.06 \\
\hline${ }^{\mathrm{d}} \mathrm{Al}$ & 0.71 & 0.002 & 0.177 & 0.03 \\
\hline${ }^{\mathrm{d}} \mathrm{Cu}$ & 0.71 & 0.003 & 0.182 & 0.09 \\
\hline dpH (bottom) & 0.71 & -0.01 & 0.297 & 0.13 \\
\hline
\end{tabular}

from SE, and the local alpine gradient (Fig. 1), implies that the study area was sufficiently large to capture macro-regional transitions in its riparian ecosystem. Longitude, while showing a separate relationship with vegetation (Table 2), played a covariate role in the multivariate model (Table 3).

\subsubsection{Catchment geomorphological and hydrological elements}

MFSO of catchment-scale variables produced a three-dimensional solution, with topography formation largely dominating hydrodynamics and geo-morphology, in its influence on vegetation 

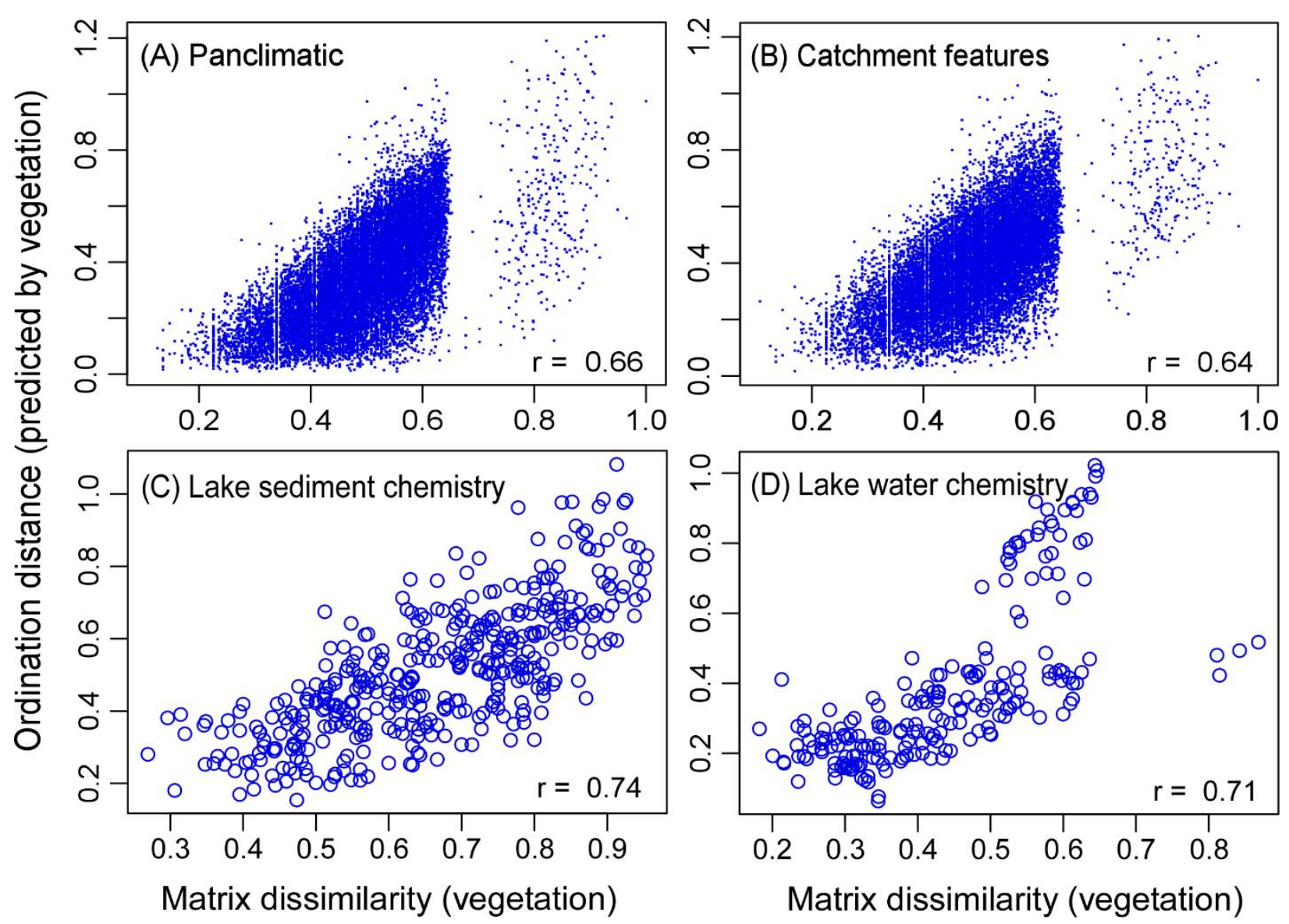

Figure 3 Multidimensional Fuzzy Set Ordination (FSO) depicting the effect of (A) large geographical gradients altitude, and latitude, (B) catchment factors topography (PC3), hydrodynamics (PC1), and geo-morphology (PC2), (C) sediment chemistry, and (D) water chemistry, on riparian plant composition. MFSO in A and B were improved by using a step-across function. Variables were introduced in the model in the order of decreasing Pearson fuzzy correlation $(r$; Table 3) with plant dissimilarity matrix. Number of permutations $=1000$.

structure (cumulative $r=0.64$; Table 3 and Fig. $3 b$ ). Since these factors are composite (Table 1), it means that catchment type - a legacy of the last glaciation, with local effects from snow cover and lake connectivity (important in propagule dispersion) create variable microclimates, which allow for colonization by different species. For instance, snow at valley head would last longer around lakes and create longer wet conditions than on mountain slopes or passes, which would experience earlier sun exposure. Previous research in alpine regions corroborates these findings and shown that topography and its effect on snow coverage can control terrestrial vegetation (Keller et al., 2005), a consequence of topography interaction with climate variables radiation, precipitation, and wind (Körner, 1999). 
Hydrodynamics added to the influence of the previous axis (Table 3 and Fig. 3b), through the nature and discharge of tributaries, and associated effects from waterbody size and nature of output (Table 1). These variables control nutrient and sediment fluxes from the drainage basin and nutrient transfer from lake area to the riparian zone. It implies that stream - fed medium to large lakes (Table 1) host significantly different vegetation than the shallower, precipitation - fed ponds.

Although its separate influence was high (Table 2), bedrock geology (with nested effects of slope, vegetation coverage, and shore development, PC2), represented the smallest driver of riparian vegetation in the multivariate model, most likely due to its covariation with topography (Table 3 and Fig. 3b). Geology is known to influence the establishment of vegetation through its control on substrate chemistry and niche formation (Kovalchik and Chitwood, 1990). The bedrock of the area presents an igneous core (granitic) in its central part, flanked by sedimentary and metasedimentary materials. Granitic geomorphology, which is more resistant to weathering, is associated with steep slopes, low vegetation coverage, less developed riparian zones (lower fractal order; Table 1), and contributes fewer nutrients to the lake. Conversely, more reactive bedrock such as limestone sustains a more nutrient - rich environment, better developed riparian zones (higher fractal order), a more stable terrain with more vegetation coverage (Table 1). Together with topographic and hydrologic particularities, the two major geological units induce the development of different riparian assemblages.

\subsubsection{Sediment chemistry. Indicator elements}

At lake scale, results of the MFSO of riparian vegetation composition and sediment major and trace element contents resulted in a bi-dimensional solution, with $\mathrm{Mg}$ and $\mathrm{Pb}$ reliably predicting species composition (cumulative $r=0.74$; Table 3 and Fig. 3c). Catchment lithology, namely the geological structure, the proportion of rock types, their mineralogy, chemistry, and weathering resistance, is tightly connected to the chemistry (major and trace elements and organic matter) of high altitude water bodies through cross-ecosystem fluxes of sediment and water (Lewin and Macklin, 1987; Zaharescu et al, 2009). Magnesium, a component of the photosynthesis molecule chlorophyll, and present in many growth enzymes, is an essential macronutrient in green plants. Soils developed on alkaline bedrock (limestone) generally contain more $\mathrm{Mg}(\approx 0.3$ 
- $2.9 \%$ ) than those on more acidic substrates (granite or sandstone; $\approx 0.01-0.3 \%$; Beeson, 1959). The results show that differences in bedrock-derived Mg can modulate vegetation community composition at species scale, in the nutrient-poor environment.

The influence of $\mathrm{Pb}$ is rather surprising. One possible explanation is that it reflects the distribution of plants using mycorrhizae since mycorrhizal symbiosis has been related with increased $\mathrm{Pb}$ uptake (Wong et al., 2007). Or, more likely, plants' natural sensitivity to $\mathrm{Pb}$ (Kabata-Pendias and Pendias, 2001) could have also changed their composition along a natural $\mathrm{Pb}$ - stress gradient. It is known that in metamorphic areas of the central Pyrenees, $\mathrm{Pb}$ is an abundant mineral constituent, and has been detected in sediment and waters in significant levels (Catalan et al., 2006; Point et al., 2007; Zaharescu et al., 2009). Likewise, metal-rich (ferromagnesian) ultramafic rocks are common in this region of the Pyrenees (Kilzi et al., 2016), and they are known to influence vegetation composition and trigger high endemism levels in mountaintop ecosystems (Galey et al., 2017). It is therefore entirely plausible that the riparian ecosystem in our study has a strong response to elements of geology richer in heavy metals than in other nutrients.

The low effect of other essential elements in the multivariate model (although high independently; Table 2) is likely due to their mineral co-occurrence and co-leaching with $\mathrm{Mg}$ and $\mathrm{Pb}$ (Spearman correlation coefficient of $\mathrm{Mg}$ with $\mathrm{Ca}, \mathrm{Fe}, \mathrm{Cr}, \mathrm{Mn}, \mathrm{Co}, \mathrm{Ni}, \mathrm{Cu}, \mathrm{Zn}$, As and $\mathrm{Ba} r>$ 0.38 , and of $\mathrm{Pb}$ with $\mathrm{Cu}$ and $\mathrm{Zn} r>0.47 ; \mathrm{P}<0.05)$. Nonetheless, plant relationship with $\mathrm{Pb}$ and Mg merit further mechanistic examination into why it is can be a dominant indicator of riparian vegetation composition.

\subsubsection{Water chemistry. Indicator elements}

The MFSO of riparian vegetation composition and selected water variables identified $\mathrm{Mn}$ and Fe as major influential axes (cumulative $r=0.73$; Table 3 and Fig. 3d). Besides collecting weathering solutes, water in snow packs affects plant growing season, as well as controlling the temperature and oxygen reaching the ecosystem. Iron and $\mathrm{Mn}$ are major redox players in soil and sediment, and varying water table can modify their solubility and uptake by plants (Alam, 1999). For instance, in the water-saturated soil, biotic respiration drives reduction processes, which affects plant performance not only by preventing nutrient ( $\mathrm{Mg}, \mathrm{Ca}$ and $\mathrm{Fe}$ ) uptake but 
also by restricting root development (Couto et al., 1983). Differential response of vegetation to the build-up of soluble $\mathrm{Fe}$ and $\mathrm{Mn}$ have been suggested in species ecology and habitat distribution (Alam, 1999), and it has been reported for grasses, legumes (Couto et al., 1983) and trees (Good and Patrick, 1987).

Variable moisture and flooding of the riparian ecosystem by lake water are common in alpine lakes, and they are regulated by snow thaw and frequency and volume of summer storms. The plant compositional change along $\mathrm{Mn}$ and Fe gradients are indicative of such process (a nested effect of topography; Table 1), with higher moisture near lakes at valley head and drier conditions on slopes and mountain passes. Unsurprisingly, water $\mathrm{pH}$, conductivity and a number of elements appeared to co-vary with Fe and $\mathrm{Mn}$ in the multivariate solution (Tables 2 and 3).

\subsubsection{Conceptual network diagram}

To illustrate the connection between riparian ecosystem and surrounding environmental features at the lake, catchment, and pan-climatic scales, a conceptual network diagram is presented in Fig. 4. The diagram shows important linkages being established between species presence, lake sediment chemistry and water redox condition, which reflects the flows of water and nutrients in the catchment. As well as with the nature of lake source and draining, shoreline development, catchment type and geology, and the large-scale altitudinal and latitudinal gradients. These landscape connections, of different strengths, and operating at different scales, are prone environmental change alteration. For instance, weak connections such as those with waterbody size, lakes connectivity, the extent of aquatic and terrestrial vegetation, and their large-scale distribution along latitude could suffer the most from deleterious effects of a changing climate. Long-range and local pollution, as well as climate change effect on weathering regimes, on the other hand, could alter the chemistry of nutrient and metal input. Increments in potentially toxic natural metal(oid) input (As and $\mathrm{Ni}$ ) has been already reported in the Pyrenees, and it has been related to reductions in precipitation frequency, elevation of spring snow line, and increase in freezing days, particularly since the 1990s (Zaharescu et al., 2016a). Existing stronger connections, on the other hand, are expected 
to weaken under drastic environmental change, while new climate and geochemical relationships could be formed.

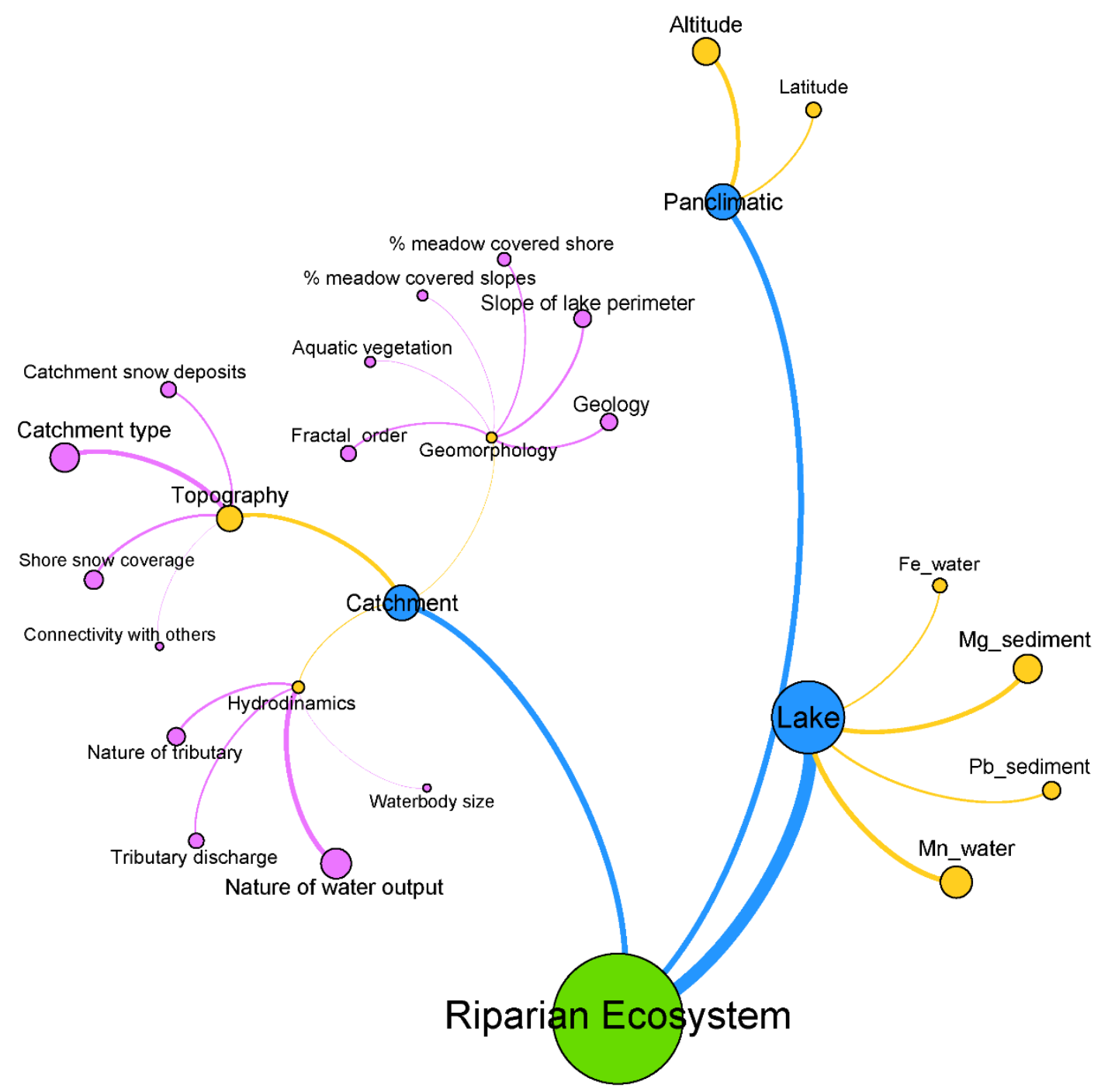

Figure 4 Conceptual network diagram showing the linkages between riparian ecosystem of a typical alpine lake and ecotopic features of the lake, catchment, and large pan-climatic gradients. Nodes and label sizes, as well as connections thickness, are proportional to the magnitude of their influence on target nodes. Connections borrow the colours of source nodes and represent different layers of organisation in the model.

\subsection{Indicator communities and their environmental preference}

\subsubsection{Community analysis}

To test whether the restrictive alpine environment harbors keystone plant communities (i.e. chorotypes; second objective), PGMA cluster analysis was used on species presence data. The 
results revealed a good grouping (agglomerative coefficient $=59 \%$ ), with the 189 lakes classified into four types (Fig. 5). Of the 168 total plant species (List S1), 79 formed four chorotypes, present

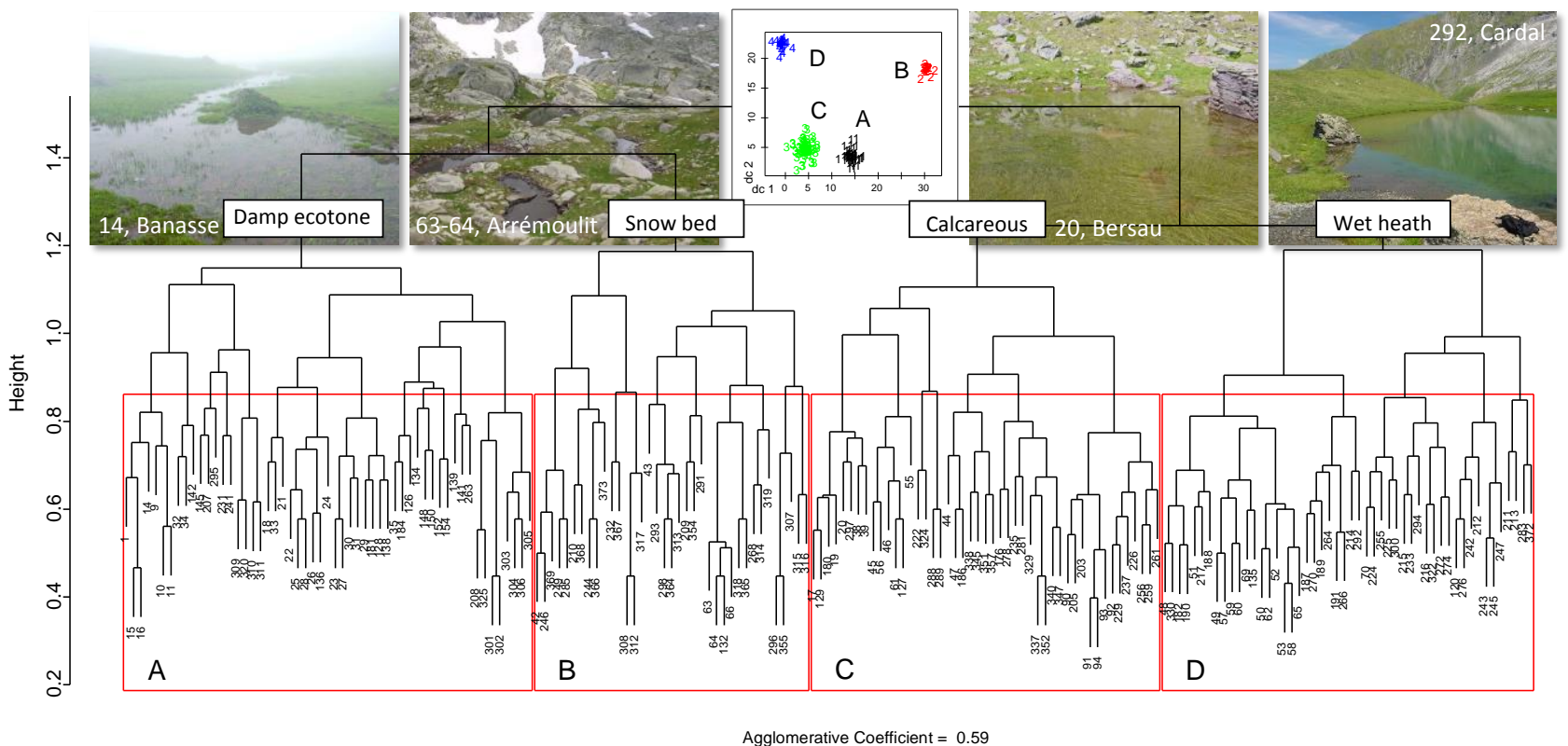

Figure 5 Dendrogram showing lake ecosystem types (clusters) based on similarity in riparian vegetation composition, together with representative examples. A plot of the clusters in discriminating space (inset) shows an effective clustering. Plant communities indicative of lake/ ecosystem types are in Table 4. N = 189 lakes and 166 plant species. Plants are listed in List S1, while lakes (at branches end) in Table S1 and Zaharescu et al., 2016b.

in the four lake environments. Table 4 shows the species with significant co-preference for each lake type and their probability of group membership. Plant communities $A, B$, and D yielded the highest degree of confidence (Fig. 5).

Type A lakes (Fig. 5 and Table 4) contain mostly species of damp ecotone. This includes bog-associated species with Sparganium, Ranunculus, Chara, Sphagnum moss, Selaginella fern, sedges (Carex) and rushes (Juncus) (Table 4). Associated with these are a limited number of plants of drier/stony habitats, including cosmopolites (Bellis), nitrogen-fixing legumes (Trifolium), and endemics (Merendera pyrenaica). The association tolerates a wide range of bedrock chemistry, including acidic (Sphagnum), neutral (Trifoliums) and basic (Polygala) substrates. This community seems to reflect an uneven physical template, common on the lake shores of the Central Pyrenees. 
The second association (type B), smaller than type A, comprises a high proportion of species of short growing season with affinity to snow bed (Saxifraga, Veronica, Sibbaldia), herbaceous shrubs (Salix), and ferns (Cryptogramma). Most of them are silicophilous, adapted to low nutrient substrate of different textures, including scree/rocky, grassland, and damp soil.

Table 4: Riparian plant groups and their fidelity to lake ecosystems (Fig. 5), as given by Indicator Species Analysis. A species was classified into a group for which its group indicator value was highest and significant. Cluster $\mathrm{C}$ had lower significance.

\begin{tabular}{|c|c|c|c|}
\hline \multicolumn{2}{|c|}{ Cluster $\mathrm{A}$, damp ecotone, $\mathrm{p}<0.05$} & \multicolumn{2}{|c|}{ Cluster $\mathrm{D}$, calcareous, $\mathrm{p}<0.05$} \\
\hline Species & Indicator value & Species & Indicator value \\
\hline Potentilla erecta & 0.47 & Pinguicula vulgaris & 0.42 \\
\hline Caltha palustris & 0.42 & Gentiana acaulis & 0.40 \\
\hline Parnassia palustris & 0.36 & Rhododendron ferrugineum & 0.35 \\
\hline Thymus serpyllum & 0.25 & Primula integrifolia & 0.30 \\
\hline Trifolium repens & 0.23 & Vaccinium uliginosum & 0.30 \\
\hline Hieracium pilosella & 0.20 & Trichophorum cespitosum & 0.29 \\
\hline Campanula rotundifolia & 0.19 & Calluna vulgaris & 0.26 \\
\hline Sphagnum sp. & 0.19 & Silene acaulis & 0.26 \\
\hline Bellis perennis & 0.18 & Trifolium alpinum & 0.25 \\
\hline Alchemilla vulgaris s.l. & 0.17 & Homogyne alpina & 0.25 \\
\hline Sparganium angustifolium & 0.15 & Soldanella alpina & 0.22 \\
\hline Carex echinata & 0.14 & Geum montanum & 0.21 \\
\hline Juncus filiformis & 0.13 & Vaccinium myrtillus & 0.21 \\
\hline Anthoxanthum odoratum & 0.13 & Hutchinsia alpina & 0.20 \\
\hline Carex nigra & 0.13 & Armeria maritima alpina & 0.19 \\
\hline Cardamine raphanifolia & 0.11 & Phyteuma orbiculare & 0.18 \\
\hline Merendera pyrenaica & 0.11 & Bartsia alpina & 0.17 \\
\hline Prunella vulgaris & 0.11 & Viola palustris & 0.17 \\
\hline Juncus articulatus & 0.11 & Geranium cinereum & 0.14 \\
\hline Leontodon autumnalis & 0.10 & Luzula alpinopilosa & 0.12 \\
\hline Ranunculus aquatilis & 0.10 & Lotus alpinus & 0.11 \\
\hline Selaginella selaginoides & 0.09 & Pedicularis mixta etc & 0.10 \\
\hline Polygala alpina & 0.09 & Thalictrum alpinum & 0.10 \\
\hline Carex flava & 0.09 & Saxifraga aizoides & 0.09 \\
\hline Polygonum viviparum & 0.08 & Gentiana lutea & 0.06 \\
\hline Carum carvi & 0.07 & & \\
\hline Galium verum & 0.07 & & \\
\hline Luzula desvauxii & 0.07 & & \\
\hline Ranunculus reptans & 0.07 & & \\
\hline Sanguisorba officinalis & 0.07 & & \\
\hline Deschampsia cespitosa & 0.06 & & \\
\hline Chara foetida & 0.05 & & \\
\hline
\end{tabular}

Cluster B, snow bed, $p<0.05$

Cluster C, wet heath, $\mathrm{p}<0.25$

\begin{tabular}{lrlr} 
Species & Indicator value & Species & Indicator value \\
\hline Gnaphalium supinum & 0.51 & Rumex crispus & 0.04 \\
Cryptogramma crispa & 0.47 & Carex flacca & 0.03 \\
Leucanthemopsis alpina & 0.34 & Cochlearia officinalis & 0.03 \\
Epilobium alsinifolium etc & 0.28 & Leontopodium alpinum & 0.03 \\
Sibbaldia procumbens & 0.25 & Oxytropis campestris & 0.03 \\
Kobresia myosuroides & 0.23 & Veronica officinalis \\
Veronica alpina & 0.22 & Callitriche palustris & 0.03 \\
Jasione montana & 0.21 & & 0.02 \\
Galium pyrenaicum & 0.19 & & \\
Poa annua etc & 0.17 & & \\
Doronicum austriacum & 0.16 & & \\
Saxifraga stellaris & 0.14 & &
\end{tabular}




\begin{tabular}{ll}
\hline Festuca eskia & 0.12 \\
Meum athamanticum & 0.10 \\
Salix herbacea & 0.10 \\
\hline
\end{tabular}

$\mathrm{N}=166$ riparian plant species from 189 water bodies.

Endemic grass Festuca eskia plotted in the same group.

Riparian community $D$ is a large community comprising wet heath species of Ericaceae shrubs (Vaccinium and Calluna), accompanied by snow bed plants (Primula, Soldanella, and Bartsia), sedges (Trichophorum), rushes (Luzula), and species of wet substrate (Pinguicula and Homogyne). In small number are species of drier habitat (Gentiana, Hutchinsia, and Phyteuma), and legumes (Trifolium). This community tolerates both, siliceous and calcareous substrates.

Community $\mathrm{C}$ was the smallest and least common ( $p<0.25$; Table 4 and Fig. 5). Its members, including the water starwort, blue-green sedge, and edelweiss (a protected species in many European countries), prefer moist-to-dry calcareous banks. Since the rest of the species had no group association, they are assumed to follow continuum or gradient distributions (Báez et al., 2005).

The identified communities incorporate species from major terrestrial groups (Gruber, 1992; Grey-Wilson and Blamey, 1995; Minot et. al, 2007), but with a preference for the wet riparian environment. They are eurytopic associations of large niche breadths, present in a wide range of habitats. This characteristic is what must have allowed them to colonize the harsh and diverse environment surrounding high - elevation waterbodies. The ecological importance of these communities, however, is that they reflect a natural ecosystem condition. Their further study in connection with climate change models is, therefore, imperative to understand how these communities, and the underlying ecotopes, cope with a changing environment.

\subsubsection{Environmental preference of indicator communities}

To better define the distribution of identified associations along environmental gradients, and understand their habitats (third objective), they were plotted against geoposition and composite catchment variables (Fig. 6). As shown by the variability in their group medians, plant communities seemed to respond well to both, large horizontal and vertical gradients, and 
catchment - scale variables. Community A inhabited water - saturated areas surrounding the larger lakes, of large (riparian) fractal order, and limited summer snow cover. They were on the floors and slopes of (meta)sedimentary glacial valleys, at comparatively low altitudes (median $\approx$ 2100 m a.s.I.) in the NE of the study area (Fig. 6). Community B, with a high proportion of snow

Altitude

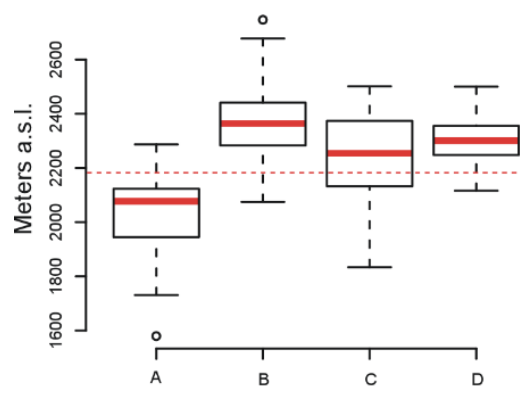

Hydrodynamics

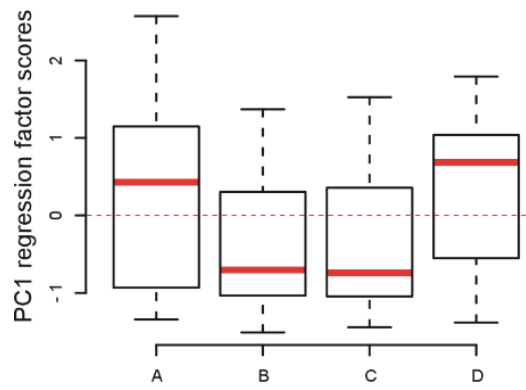

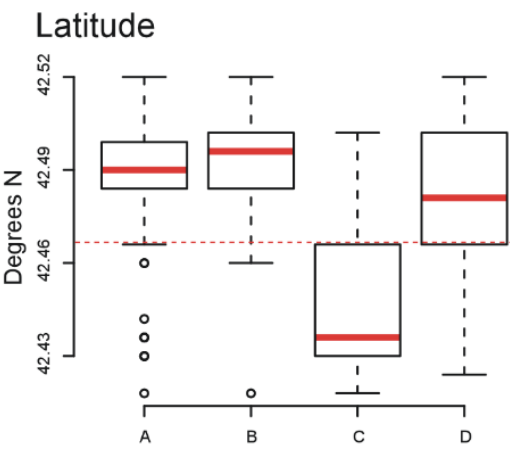

Geo-morphology

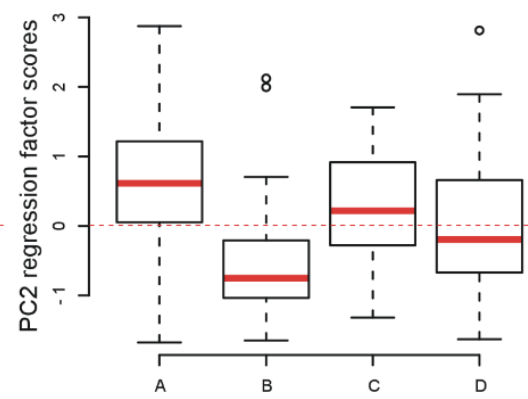

Longitude

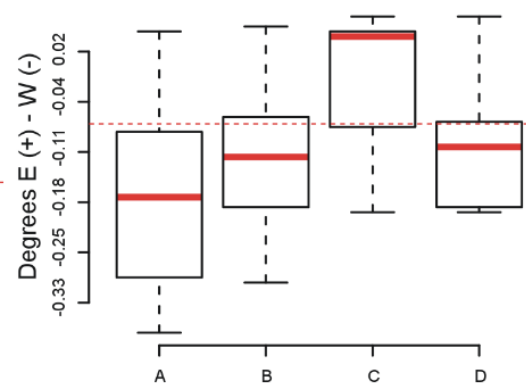

Topography formation

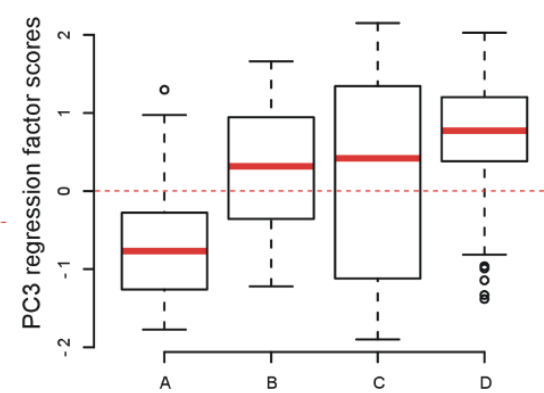

Figure 6 Boxplots showing the distribution of indicator plant communities along geoposition (altitude, latitude, and longitude) and composite catchment gradients. Hydrodynamics factor ranges from small water bodies (-) to large lakes $(+)$, and their associated variables (Table 1); geo-morphology, from igneous and metamorphic $(-)$, to sedimentary $(+)$; topography formation from valley floor and flat topography $(-)$, to valley head $(+)$. Boxplots represent median (red), first (25\%) and third (75\%) quartiles, with whiskers extending to the 5th and 95th percentiles. Horizontal dashed red lines are set at plot averages.

bed species, grew in elevated granitic topography (e.g. glacial valleys head and mountain pass, $\approx 2400 \mathrm{~m}$ a.s.l., the central part of the region), of steep slopes and low fractal development. These habitats (mostly rain-fed lakes) had persistent summer snow cover and lower water turnover. Association type $\mathrm{C}$ established around small lakes of low input/output, in a wide range of altitude and topography, from valley floors to valley heads, in the SW of the study area (Fig. 6). Community D, of the narrowest altitude span, was mostly found inhabiting large catchment head lakes with persistent summer snow and high water turnover, in the central area. 
These results support findings from community analysis and clearly show that none of the evaluated ecotope factors was the sole driver of community establishment in the intricate topography. Rather, a complex pool of microclimatic and geomorphologic conditions worked together to sustain the riparian communities. Since these communities reflect environmental gradients sustaining their formation, their long-term study is necessary, as climate change can affect their distribution through effects on the underlying physicochemical drivers.

\subsubsection{Environmental change and protection approaches}

Anthropogenic effects on climate, long-range atmospheric transport of pollutants (e.g. black carbon and heavy metals), and direct human encroachment (mining, farming, military activity and tourism/urbanization) can significantly affect pristine alpine environments, with potentially irremediable effects (Kohler et al., 2014; Huss et al., 2017). These can range from habitat loss due to species introduction, climate-enhanced diseases, altitudinal range shifts in species, waterbodies pollution, and loss of natural connectivity.

Climate change effects on precipitation, snow line, hydrology and weathering fluxes have been reported in the alpine and subalpine Pyrenees (Zaharescu et al., 2016a). This could affect riparian communities in various way. For instance, snow bed communities ( $B$ and $D$; in the central part of the study area; Fig. 6) could experience decreasing snow in their habitats, earlier springs, and dryer, longer summers. Since both communities also occupy the higher altitudes overall, competition from advancing low - altitude species could increase their fragmentation, species rearrangement in new communities and loss, particularly of endemic species. Changes in nutrient load from increased weathering, tourist-hosting industry, and aerial pollution can also preferentially affect community $B$, which is adapted to lower nutrient concentrations. Metal abundances in some catchments of the study area are high (Kilzi et al., 2016; Point et al., 2007), and they have been shown to increment under climate change, to potentially toxic levels in other regions of the Pyrenees (Zaharescu et al., 2016a). This can result in loss of less tolerant species, particularly those on metasedimentary materials (e.g. community A), in the lower, west front of the area Fig.6).

While this study explores natural linkages in a protected region, the sensitivity of riparian environments to both, aquatic and terrestrial stressors should bring them at the 
forefront of environmental protection strategies. Education approaches that promote the value of natural landscapes for current and future generations in a holistic way (biosphere, geosphere, hydrosphere and atmosphere coupling) should be prioritized, as well as long-term conservational approaches. Global scale collaborative efforts on long-term monitoring, e.g. Mountain Research Initiative (http://mri.scnatweb.ch/en/), Global Lake Ecological Observatory Network (http://gleon.org/) and Critical Zone Observatory Network (criticalzone.org/), setting up alpine research centres and botanical gardens, and citizen science (Zaharescu et al, 2006, 2007; Mix, 2014), could help improve the perception of mountain ecosystems as centres of biodiversity, providers of mental health benefits, and important players in the distribution of natural resources to the wider biosphere.

\section{CONCLUSIONS}

Results show that the connections between alpine riparian ecosystem and the surrounding aquatic and terrestrial environments extend over a wide range of scales. Topographical formations left behind by the last glaciation, with contemporary effects of snow cover and lake connectivity, are the dominant catchment-scale elements controlling ecosystem development and diversity. Hydrodynamics, with nested contribution from size and nature of the lake and its input and output, was the second to topography. The two suggest that these lake ecosystems are not isolated 'islands' in the landscape, but rather interconnected biodiversity nodes, controlled by the catchment physical elements. Geo-morphology, grouping geology, slope and complexity of shore line, and its vegetation cover, greatly covaried with the first two factors, and reflected major geomorphological units, extending from igneous, to metasedimentary and calcareous sedimentary materials. Geology also exerted local effects (through sediment $\mathrm{Mg}$ and $\mathrm{Pb}$ and water $\mathrm{Mn}$ and Fe) likely due to linkages with mafic and ultramafic materials. Superimposed to catchment and local drivers, the ecosystem captured the transition between major biogeographic regions of Europe, in an otherwise narrow study area.

The riparian ecotone, connecting complex topography, geology and water regimes, assembled species from both wet and dry environments, which withstand regular flooding. Community analysis identified four such eurytopic groups, i.e. damp ecotone, snow bed- 
silicates, calcareous, and wet heath. They have a broad niche breadth and characterise four ecosystem/lake types. The distribution and habitat preference of these communities are telltales of their sensitivity to a number of environmental change factors, including diminishing snow cover, modification in water level, increased nutrient and metal input from tourism industry and weathering of natural metal stores, increased fragmentation and competition from lowland species.

The riparian-aquatic and riparian-terrestrial connections shown by this study clearly illustrate how physical, geochemical and hydrological elements of the alpine landscape aggregate into major ecotope drivers, and operate at different scale to shape the composition and distribution of the overlying ecosystem. It remains to be seen how the environmental change affects the functional connectivity of these water-sensitive ecosystems with the supporting ecotope, at its manifold of scales.

\section{ACKNOWLEDGEMENTS}

This research was funded by the Pyrenees National Park (France; contracts no. 2000.40S, 2001.09S, and 2002.25S) through a survey grant awarded in 2000 - 2002. The authors recognize the great effort of the expedition, analysis and logistics teams, including Javier FernandezFañanas, Jorge Milos, Andreea Vasiloiu, Nicolas Palanca-Castán, Bruce Dudley, Jesús GiraldezMoreira, Cristina Castan-Lanaspa, David Rodríguez-Vieites, Manuel Domínguez-Rey, Ana Quintillán-Cortiñas, Belén Cirujano-Díaz, Roberto García-Carrera, Jorge Diez-Dieguez, Jorge Rodriguez-Vila, Claudia Toda-Castán, Juan Fernández-Rodríguez, Carles Roselló-Vila, Carlos TurLahiguera, Nuria Marti, Maria José Ferrus-Leiva, Julio Palanca-Castán and José Martín-Gallardo. We would also like to extend our gratitude to Dave Roberts (Montana State University, USA), Lasse Ruokolainen (Helsinki University) and several anonymous reviewers, for their thoughtful suggestions, which significantly improved the manuscript.

\section{AUTHORS CONTRIBUTION}

Research grant design, A. Palanca-Soler; field data collection, R.N. Lester (plant taxonomy), C. Tanase (plant taxonomy), A. Palanca-Soler and D.G. Zaharescu; study design and manuscript 
preparation D.G. Zaharescu, P.S. Hooda and C.I. Burghelea. The authors assert no competing interests.

\section{REFERENCES}

Alam SM. 1999. Nutrient uptake by plants under stress conditions. In: Pessarakli M. (Ed), Handbook of plant and crop stress, $2^{\text {nd }}$ ed. revised and expanded. Marcel Dekker, New York, USA: $285-314$.

Austin MP, Smith TM. 1989. A new model for the continuum concept. Vegetatio 83: 35-47.

Báez JC, Real R, Mario-Vargas J, Flores-Moya A. 2005. Chorotypes of seaweeds from the western Mediterranean Sea and the Adriatic Sea: An analysis based on the genera Audouinella (Rhodophyta), Cystoseira (Phaeophyceae) and Cladophora (Chlorophyta). Phycol Res 53: 255-265.

Baker WL. 1989. Macro- and micro-scale influences on riparian vegetation in Western Colorado. Ann Assoc Am Geogr 79(1): 65-78.

Bastian M, Heymann S, Jacomy M. 2009. Gephi: an open source software for exploring and manipulating networks. International AAAI Conference on Weblogs and Social Media.

Baroni-Urbani C, Ruffo S, Vigna-Taglianti A. 1978. Materiali per una biogegrafia italiana fondata su alcuni generi di coleotteri cicindelidi, carabidi e crisomelidi. Estr Mem Soc Ent Ital 56: 3592.

Beeson KC. 1959. Magnesium in soil-sources, availability and zonal distribution. In: Magnesium and agriculture, Proceedings of the symposium; Anderson GC, Jencks EM, Horvath DJ (Eds), West Virginia University, Morgantown: 1-11.

Boyce R. 2008. Fuzzy set ordination web page. Northern Kentucky University. Accessed: August 2009 from http://www.nku.edu/ boycer/fso/.

Boyce RL, Ellison PC. 2001. Choosing the best similarity index when performing fuzzy set ordination on binary data. J Veg Sci 12: 711-20. 
Buma B, Hennon PE, Harrington CA, Popkin JR, Krapek J, Lamb MS, Oakes LE, Saunders S, Zeglen S. 2016. Emerging climate-driven disturbance processes: widespread mortality associated with snow-to-rain transitions across $10^{\circ}$ of latitude and half the range of a climatethreatened conifer. Global Change Biology. DOI: 10.1111/gcb.13555.

Burghelea, C.I. et al., 2015. Mineral nutrient mobilization by plant from rock: Influence of rock type and arbuscular mycorrhiza. Biogeochemistry 124: 187-203.

Castillo-Jurado M. 1992. Morfometria de los lagos. Una aplicacion a los lagos del Pirineo. PhD thesis, University of Barcelona (in Spanish).

Catalan J, Camarero L, Felip M, Pla S, Ventura M, Buchaca T, Bartumeus F, De Mendoza G, Miró A, Casamayor EO, Medina-Sánchez JM, Bacardit M, Altuna M, Bartrons M, De Quijano DD. 2006. High mountain lakes: extreme habitats and witnesses of environmental changes. Limnetica 25(1-2): 551-584.

Couto W, Sanzonowics C, Leite GG. 1983. Effect of excess water in an oxisol on ammonium, nitrate, iron and manganese availability and nutrient uptake of two tropical forage species. Plant Soil 73: 159-166.

Dufrene M, Legendre P. 1997. Species assemblages and indicator species: the need for a flexible asymmetrical approach. Ecol Monogr 67(3): 345-366.

EEA (European Environment Agency). 2001. Biogeographical regions, Europe 2001. Available online at http://www.eea.europa.eu/data-and-maps/figures/biogeographical-regionseurope-2001. Accessed February 04, 2010.

Engelhardt BM, Chambers JC, Weisberg PJ. 2015. Geomorphic predictors of riparian vegetation in small mountain watersheds. Journal of Plant Ecology 8 (6): 593-604.

Fattorini, S., 2015. On the concept of chorotype. Journal of Biogeography 42: 2246-2251.

Fitter RSR, Fitter A, Farrer A. 1984. Grasses, sedges, rushes and ferns of Britain and Northern Europe. Collins, London, UK.

Galey ML, Van der Ent A, Iqbal MCM, Rajakaruna N. 2017. Ultramafic geoecology of South and Southeast Asia. Bot Stud 58: 18.

García-Rollán M. 1985. Claves de la flora de España (peninsula y Baleares). Vol.II: dicotiledoneas (I-z) / monocotiledoneas. Mundi-Prensa [in Spanish]. 
Gómez D, Sesé JA, Villar L. 2003. The vegetation of the alpine zone in the Pyrenees. In: Alpine biodiversity in Europe, Nagy L, Grabherr G, Körner Ch, Thompson DBA (Eds). Ecol Studies 167: 85-92.

Good BJ, Patrick Jr, WH. 1987. Gas composition and respiration of water oak (Quercus nigra L.) and green ash (Fraxinus pennsylvanica Marsh.) roots after prolonged flooding. Plant Soil 97: 419-27.

Gregory SV, Swanson FJ, McKee WA, Cummins KW. 1991. An ecosystem perspective of riparian zones: focus on links between land and water. BioScience 41(8): 540-549.

Grey-Wilson C, Blamey M. 1979. The alpine flowers of Britain and Europe. Collins, London, UK. Grey-Wilson C, Blamey M. 1995. The alpine flowers of Britain and Europe. Collins, London, UK. Gruber M. 1992. Schéma des séries dynamiques de végétation des Hautes-Pyrénées (Pyrénées centrales francaises). Bot Complutensis 17: 7-21.

Hagmann P. 2005. From Diffusion MRI to Brain Connectomics. Science 3230: 127.

Hengeveld R. 1990. Dynamic biogeography. Cambridge University Press, Cambridge.

Hennig C. 2005. A method for visual cluster validation. In: Weihs C, Gaul W (eds). Classification The Ubiquitous Challenge. Springer, Heidelberg 2005: 153-160.

Huss M, Bookhagen B, Huggel C, Jacobsen D, Bradley R, Clague J, Vuille M, Buytaert W, Cayan D, Greenwood G, Mark B, Milner A, Weingartner R, Winder M. 2017. Towards mountains without permanent snow and ice. Earth's Future. doi:10.1002/2016EF000514

Kabata-Pendias A, Pendias H. 2001. Trace elements in soils and plants. $3^{\text {rd }}$ ed. CRC Press LLC, USA.

Kaufman L, Rousseeuw PJ. 1990. Finding groups in data: an introduction to cluster analysis. Wiley, New York.

Keller F, Goyette S, Beniston M. 2005. Sensitivity analysis of snowcover to climate change scenarios and their impact on plant habitats in alpine terrain. Clim Change 72: 299-319.

Kernan M, Ventura M, Bitušík P, Brancelj A, Clarke G, Velle G, Raddum GG, Stuchlík E, Catalan J. 2009. Regionalisation of remote European mountain lake ecosystems according to their biota: environmental versus geographical patterns. Freshwat Biol 54 (12): 2470 -93. 
Khamis K, Hannah DM, Brown LE, Tiberti R, Milner a. M. 2014. The use of invertebrates as indicators of environmental change in alpine rivers and lakes. Sci Total Environ 493: 124254.

Kilzi MA, Grégoire M, Bosse V, Benoît M, Driouch Y, De Saint Blanquat M, Debat P. 2016. Geochemistry and zircon $\mathrm{U}-\mathrm{Pb}$ geochronology of the ultramafic and mafic rocks emplaced within the anatectic series of the Variscan Pyrenees: The example of the Gavarnie-Heas dome (France), C R Geosci, 348(2): 107-115.

Kohler T, Wehrli A, Jurek M (eds). 2014. Mountains and climate change: A global concern. Sustainable Mountain Development Series. Bern, Switzerland, Centre for Development and Environment (CDE), Swiss Agency for Development and Cooperation (SDC) and Geographica Bernensia. $136 \mathrm{pp}$.

Körner Ch. 1999. Alpine plant life: functional plant ecology of high mountain ecosystems. Springer, Berlin Heidelberg. 343 pp.

Kovalchik BL, Chitwood LA. 1990. Use of geomorphology in the classification of riparian plant associations in mountainous landscapes of central Oregon, U.S.A. For Ecol Manage 33/34: 405-418.

Kreyling J, Jentsch A, Beier C. 2014. Beyond realism in climate change experiments: gradient approaches identify thresholds and tipping points. Ecol Lett 17: 125-e1.

Larsen IJ, Montgomery DR, Greenberg HM. 2014. The contribution of mountains to global denudation. Geology 42(6): 527-530.

Lewin J, Macklin MG. 1987. Metal mining and floodplain sedimentation in Britain. In: Gardiner V (ed). International geomorphology, part 1. Chichester, Wiley: 1009-27.

Loucks OL. 1962. Ordinating forest communities by means of environmental scalars and phytosociological indices. Ecol Monogr 32: 137-166.

Merritt DM, Scott ML, Poff NL, Auble GT, Lytle DA. 2010. Theory, methods and tools for determining environmental flows for riparian vegetation: riparian vegetation-flow response guilds. Freshwat Biol 55: 206-225.

Minot JM, Carrillo E, Font X, Carreras J, Ferré A, Masalles RM, Soriano I, Vigo J. 2007. Altitude zonation in the Pyrenees. A geobotanic interpretation. Phytocoenologia 37 (3-4): 371-398. 
Mix H. 2014. Integrating Alpine Adventure and Citizen Science in the Greater Himalaya. American Geophysical Union Fall Meeting, San Francisco.

Oksanen J, Kindt R, Legendre P, O'Hara B, Simpson GL, Solymos P, Stevens MHH, Wagner H. 2009. Vegan: community ecology package. R package version 1.15-4. http://CRAN.Rproject.org/package=vegan .

Parker BR, Vinebrooke RD, Schindler DW. 2008. Recent climate extremes alter alpine lake ecosystems. Proc Natl Acad Sci U S A 105: 12927-31.

Point D, Bareille G, Amouroux D, Etcheber H, Donarda OFX. 2007. Reactivity, interactions and transport of trace elements, organic carbon and particulate material in a mountain range river system (Adour River, France). J Environ Monit 9: 157-167.

Price MF (ed). 2004. Conservation and sustainable development in mountain areas. IUCN, Gland, Switzerland and Cambridge, UK. 29 pp.

R Core Development Team. 2005. R: a language and environment for statistical computing. R Foundation for Statistical Computing, Vienna, Austria (http://www.R-project.orgi).

Roberts DW. 1986. Ordination on the basis of fuzzy set theory. Vegetatio 66: 123-131.

Roberts DW. 2007(a). FSO: fuzzy set ordination. R package version 1.0-1 (http://cran.Rproject.orgi).

Roberts DW. 2007(b). LabDSV: ordination and multivariate analysis for ecology. R package version 1.3-0 (http://cran.R-project.orgi).

Roberts DW. 2008. Statistical analysis of multidimensional fuzzy set ordinations. Ecology 89: $1246-1260$.

Roberts DW. 2009(a). Comparison of multidimensional fuzzy set ordination with CCA and DBRDA. Ecology 90(9): 2622-34.

Roberts DW. 2009(b). Fuzzy set ordination, R labs for vegetation ecologists, Montana State University. http://ecology.msu.montana.edu/labdsv/R/labs/lab11/lab11.html. Accessed August 2009.

Sporns O. 2006. Small-world connectivity, motif composition, and complexity of fractal neuronal connections. BioSystems 85: 55-64. 
Storkey J, Macdonald AJ, Poulton PR, Scott T, Köhler IH, Schnyder H, Goulding KWT, Crawley MJ. 2015. Grassland biodiversity bounces back from long-term nitrogen addition. Nature, 528(7582): 401-404.

Thioulouse J, Chessel D, Doledee S, Olivier JM. 1997. ADE-4 A multivariate analysis and graphical display software. Stat Comput 7: 75-83.

Thompson R, Kamenik C, Schmidt R. 2005. Ultra-sensitive Alpine lakes and climate change. J Limnol 64: 139-52.

Thornbury WD. 1969. Principles of geomorphology, 2nd Ed., John Wiley and Sons, Inc., New York.

Verardo DJ, Froelich PN, Mclntyre A. 1990. Determination of organic carbon and nitrogen in marine sediments using the Carlo Erba NA-1500 Analyzer. Deep-Sea Res. Part A, 37: 157165.

Whittaker RH. 1967. Gradient analysis of vegetation. Biol Rev 42: 207-264.

Williamson C, Saros JE, Vincent WF, Smol JP. 2009. Lakes and reservoirs as sentinels, integrators, and regulators of climate change. Limnol Oceanogr 54: 2273-82.

Wong CC, Wu SC, Kuek C, Khan AG, Wong MH. 2007. The role of mycorrhizae associated with vetiver grown in Pb-/Zn-contaminated soils: Greenhouse study. Restor Ecol 15(1): 60-67.

Zaharescu DG, Palanca-Soler A, Burghelea Cl, Palanca-Castan N. 2006. Alpine collections at high altitudes: Implementing a new educational strategy in the Central Pyrenees. Botanic Gardens Conservation International (BGCl). Proceedings of the 6th International Congress on Education in Botanic Gardens, Oxford, UK: 1-10.

Zaharescu DG, Burghelea Cl, Stanc S., Palanca-Soler A. 2007. Aragonese High Mountain Flora and Fauna Research Centre and Postgraduate Programme: Ecological and Earth Sciences in High Mountains. Phenology and Anatomy, Special Issue, ISSN: $1138=6118$.

Zaharescu DG, Hooda PS, Fernandez J, Soler AP, Burghelea Cl. 2009. On the arsenic-source mobilisation and its natural enrichment in the sediments of a high mountain cirque in the Pyrenees. J Environ Monit 11: 1973-1981.

Zaharescu DG, Burghelea Cl, Hooda PS, Polyakov V, Palanca-Soler A. 2016(a). Climate change enhances the mobilisation of naturally occurring metals in high altitude environments. The 
DOI (Science of the Total Environment 2017): http://dx.doi.org/10.1016/j.scitotenv.2017.05.135

Science of the Total Environment 560-561: 73-81.

Zaharescu DG, Hooda PS, Burghelea Cl, Palanca-Soler A. 2016(b). A multiscale framework for deconstructing the ecosystem physical template of high altitudes lakes. Ecosystems 19 (6): 1064-1079.

Zaharescu DG, Burghelea Cl, Hooda PS, Lester RN, Palanca-Soler A. 2016(c). Small lakes in big landscape: Multi-scale drivers of littoral ecosystem in alpine lakes. The Science of the Total Environment 551-552: 496-505.

Zakharova EA, Pokrovsky OS, Dupré B, Gaillardet J, Efimova LE. 2007. Chemical weathering of silicate rocks in Karelia region and Kola peninsula, NW Russia: Assessing the effect of rock composition, wetlands and vegetation. Chemical Geology 242: 255-277.

\title{
SUPPORTING INFORMATION
}

\section{Riparian vegetation in the alpine connectome. Terrestrial-aquatic and terrestrial-terrestrial interactions}

\author{
D.G. Zaharescu A. Palanca-Soler, P.S. Hooda, C. Tanase, C.I. Burghelea, R. N. Lester
}

Table S1. Lakes from the axial region of the Pyrenees National Park (France) surveyed for this study, their geographical position and surface area. A Google Earth map file with a representative subset of lakes is available on the article webpage. Major lakes in a catchment have no suffix, while waterbodies lacking names were given the name of their surrounding area. $\left(^{*}\right)$ represents dam closing. Multiple year sampling is illustrated in brackets.

\begin{tabular}{|c|c|c|c|c|c|c|c|}
\hline $\begin{array}{l}\text { Lake } \\
\text { ID }\end{array}$ & Sampling year & Name & $\begin{array}{l}\text { Main } \\
\text { valley }\end{array}$ & $\begin{array}{l}\text { Altitude } \\
(\mathrm{m})\end{array}$ & Latitude & Longitude & $\begin{array}{l}\text { Area } \\
\left(\mathrm{m}^{2}\right)\end{array}$ \\
\hline$\overline{1}$ & 2002 & Lake Arlet & Aspe & 1987 & 42.5021 & -0.3653 & 31037.00 \\
\hline 9 & 2002 & Pond Caillaous & Aspe & 1877 & 42.4954 & -0.3607 & 108.19 \\
\hline 10 & 2002 & Pond Caillaous 1 & Aspe & 1877 & 42.4954 & -0.3607 & 388.77 \\
\hline 11 & 2002 & Lake Gourgue & Aspe & 1840 & 42.4954 & -0.3607 & 1295.91 \\
\hline 14 & 2002 & Lake Banasse 1 & Aspe & 1940 & 42.4954 & -0.3607 & 742.20 \\
\hline 15 & 2002 & Lake Banasse 2 & Aspe & 1940 & 42.4954 & -0.3607 & 1178.10 \\
\hline 16 & 2002 & Lake Banasse 3 & Aspe & 1940 & 42.4954 & -0.3607 & 2450.44 \\
\hline 17 & 2001 & Lake Bersau & Ossau & 2082 & 42.4959 & -0.3015 & 79223.11 \\
\hline 18 & 2001 & Lake Berseau 1 & Ossau & 2080 & 42.4959 & -0.3015 & 1484.40 \\
\hline 19 & 2001 & Lake Berseau 2 & Ossau & 2100 & 42.4959 & -0.3015 & 2419.81 \\
\hline 20 & 2001 & Pond Berseau 1 & Ossau & 2085 & 42.4959 & -0.3015 & 127.23 \\
\hline 21 & 2001 & Pond Berseau 2 & Ossau & 2086 & 42.4959 & -0.3015 & 180.64 \\
\hline 22 & 2001 & Lake Larry 1 & Ossau & 2077 & 42.5018 & -0.3014 & 1162.39 \\
\hline
\end{tabular}




\begin{tabular}{|c|c|c|c|c|c|c|c|}
\hline 23 & 2001 & Lake Larry 2 & Ossau & 2077 & 42.5018 & -0.3014 & 293.74 \\
\hline 24 & 2001 & Lake Larry 3 & Ossau & 2077 & 42.5018 & -0.3014 & 414.69 \\
\hline 25 & 2001 & Lake Larry 4 & Ossau & 2077 & 42.5018 & -0.3014 & 306.31 \\
\hline 26 & 2001 & Lake Ayous 1 & Ossau & 2060 & 42.5018 & -0.2929 & 722.57 \\
\hline 27 & 2001 & Lake Ayous 2 & Ossau & 2060 & 42.5018 & -0.2929 & 753.96 \\
\hline 28 & 2001 & Lake Ayous 3 & Ossau & 2060 & 42.5018 & -0.2929 & 769.69 \\
\hline 29 & 2001 & Lake Gentau 1 & Ossau & 1982 & 42.5018 & -0.2929 & 1850.40 \\
\hline 30 & 2001 & Lake Gentau & Ossau & 1947 & 42.5018 & -0.2929 & 107068.62 \\
\hline 31 & 2001 & Lake Miey & Ossau & 1920 & 42.5018 & -0.2929 & 9324.25 \\
\hline 32 & 2001 & Lake Roumassot & Ossau & 1845 & 42.5018 & -0.2929 & 55694.15 \\
\hline 33 & 2001 & Lake Castérau & Ossau & 1943 & 42.4945 & -0.2931 & 15013.67 \\
\hline 34 & 2001 & Lake Paradis & Ossau & 1976 & 42.4945 & -0.2931 & 9495.97 \\
\hline 35 & 2001 & Lake Peyreget & Ossau & 2074 & 42.4942 & -0.2719 & 10568.01 \\
\hline 38 & 2001 & Lake Col de Peyreget 1 & Ossau & 2220 & 42.4941 & -0.2635 & 1473.41 \\
\hline 39 & 2001 & Lake Col de Peyreget 2 & Ossau & 2208 & 42.4941 & -0.2635 & 3758.13 \\
\hline 42 & 2001 & Lake Arrémoulit Supérieur & Ossau & 2281 & 42.5005 & -0.1957 & 39654.75 \\
\hline 43 & 2001 & *Lake Arrémoulit & Ossau & 2285 & 42.5037 & -0.1956 & 72184.37 \\
\hline 44 & 2001 & Lake Arrémoulit (bellow dam) & Ossau & 2255 & 42.5037 & -0.1956 & 9680.03 \\
\hline 45 & 2001 & Lake Palas & Ossau & 2359 & 42.5037 & -0.1956 & 6856.53 \\
\hline 46 & 2001 & Lake Palas 1 & Ossau & 2365 & 42.5037 & -0.1956 & 2511.70 \\
\hline 47 & 2001 & Lake Palas 2 & Ossau & 2362 & 42.5037 & -0.1956 & 1226.79 \\
\hline 48 & 2001 & Lake Arrémoulit Superior 1 & Ossau & 2300 & 42.5037 & -0.1956 & 1272.35 \\
\hline 49 & 2001 & Lake Arrémoulit Superior 2 & Ossau & 2295 & 42.5037 & -0.1956 & 208.92 \\
\hline 50 & 2001 & Lake Arrémoulit Superior 3 & Ossau & 2297 & 42.5037 & -0.1956 & 23.56 \\
\hline 51 & 2001 & Lake Arrémoulit Superior 4 & Ossau & 2300 & 42.5037 & -0.1956 & 2104.08 \\
\hline 52 & 2001 & Lake Arrémoulit Superior 5 & Ossau & 2300 & 42.5037 & -0.1956 & 1503.25 \\
\hline 53 & 2001 & Lake Arrémoulit Superior 6 & Ossau & 2305 & 42.5037 & -0.1956 & 1237.00 \\
\hline 55 & 2001 & Lake Arrémoulit Superior 7 & Ossau & 2290 & 42.5037 & -0.1956 & 384.85 \\
\hline 56 & 2001 & Lake Arrémoulit Superior 8 & Ossau & 2285 & 42.5037 & -0.1956 & 144.51 \\
\hline 57 & 2001 & Lake Arrémoulit Inférieur & Ossau & 2241 & 42.5037 & -0.1956 & 9671.11 \\
\hline 58 & 2001 & Lake Arrémoulit Inferior 1 & Ossau & 2248 & 42.5037 & -0.1956 & 292.17 \\
\hline 59 & 2001 & Lake Arrémoulit Inferior 2 & Ossau & 2246 & 42.5037 & -0.1956 & 2831.36 \\
\hline 60 & 2001 & Lake Arrémoulit Inferior 3 & Ossau & 2244 & 42.5037 & -0.1956 & 4970.00 \\
\hline 61 & 2001 & Lake Arrémoulit Inferior 4 & Ossau & 2256 & 42.5037 & -0.1956 & 523.85 \\
\hline 62 & 2001 & Lake Arrémoulit Inferior 5A & Ossau & 2254 & 42.5037 & -0.1956 & 282.74 \\
\hline 63 & 2001 & Lake Arrémoulit Inferior 5B & Ossau & 2254 & 42.5037 & -0.1956 & 271.74 \\
\hline 64 & 2001 & Lake Arrémoulit Inferior 5C & Ossau & 2254 & 42.5037 & -0.1956 & 278.02 \\
\hline 65 & 2001 & Lake Arrémoulit Inferior 5D & Ossau & 2254 & 42.5037 & -0.1956 & 266.24 \\
\hline 66 & 2001 & Lake Arrémoulit Inferior 6 & Ossau & 2252 & 42.5037 & -0.1956 & 197.92 \\
\hline 69 & 2002 & Lake Carnau 1 & Ossau & 2208 & 42.5213 & -0.1908 & 34321.90 \\
\hline 70 & 2002 & Lake Carnau 2 & Ossau & 2202 & 42.5213 & -0.1908 & 9291.26 \\
\hline 90 & 2002 & Lake Les Lacarrats_1 & Azun & 2441 & 42.5212 & -0.1824 & 490.87 \\
\hline 91 & 2002 & Lake Les Lacarrats_2 & Azun & 2441 & 42.5212 & -0.1824 & 235.62 \\
\hline 92 & 2002 & Lake Les Lacarrats_3 & Azun & 2429 & 42.5212 & -0.1824 & 4594.58 \\
\hline 93 & 2002 & Lake Les Lacarrats_4 & Azun & 2430 & 42.5212 & -0.1824 & 9825.33 \\
\hline 94 & 2002 & Lake Les Lacarrats_5 & Azun & 2430 & 42.5212 & -0.1824 & 7657.63 \\
\hline 120 & 2001 & Lake Micoulaou 1 & Azun & 2302 & 42.5034 & -0.1744 & 706.84 \\
\hline 126 & $2000(125 / 2001)$ & Lake Batcrabère Supérieur & Azun & 2180 & 42.5034 & -0.1744 & 79168.13 \\
\hline 127 & 2001 & Lake Batcrabère Supérieur 1 & Azun & 2182 & 42.5034 & -0.1744 & 285.88 \\
\hline 128 & 2001 & Lake Batcrabére Milieu & Azun & 2130 & 42.5034 & -0.1744 & 1923.44 \\
\hline 129 & 2001 & Pond Batcrabére Milieu 1 & Azun & 2130 & 42.5106 & -0.1743 & 47.12 \\
\hline 132 & 2001 & $\begin{array}{l}\text { Lake bellow Batcrabére } \\
\text { Milieu }\end{array}$ & Azun & 2129 & 42.5034 & -0.1744 & 1755.31 \\
\hline 134 & $2000(133 / 2001)$ & Lake Batcrabère Inférieur & Azun & 2116 & 42.5106 & -0.1743 & 18606.08 \\
\hline 135 & 2001 & Lake Batcrabère Inférieur 1 & Azun & 2116 & 42.5106 & -0.1743 & 3573.56 \\
\hline 136 & 2001 & Pond next to Larribet Refuge & Azun & 2055 & 42.5106 & -0.1743 & 1979.20 \\
\hline
\end{tabular}




\begin{tabular}{|c|c|c|c|c|c|c|c|}
\hline 138 & $2000(137 / 2001)$ & Pond Pabat & Azun & 2062 & 42.5106 & -0.1743 & 518.35 \\
\hline 139 & 2001 & Lake La Claou Supérieur & Azun & 1750 & 42.521 & -0.1656 & 2964.09 \\
\hline 141 & $2000(140 / 2001)$ & Lake La Claou & Azun & 1739 & 42.521 & -0.1656 & 2035.75 \\
\hline 142 & 2001 & Lake Doumblas & Azun & 1580 & 42.5209 & -0.1612 & 1796.99 \\
\hline 145 & 2001 & Pond Pluviometre & Azun & 1731 & 42.5135 & -0.1529 & 4546.54 \\
\hline 148 & $2001(147 / 2000)$ & Lake Remoulis Inférieur & Azun & 2017 & 42.5031 & -0.1532 & 5340.71 \\
\hline 150 & $2001(147 / 2000)$ & Lake Remoulis Supérieur & Azun & 2019 & 42.5031 & -0.1532 & 12801.99 \\
\hline 152 & $2001(151 / 2000)$ & Pond Casteric & Azun & 2080 & 42.4958 & -0.1533 & 659.73 \\
\hline 154 & $2001(153 / 2000)$ & Pond Toue & Azun & 2090 & 42.4958 & -0.1533 & 639.31 \\
\hline 176 & 2001 & Lake Cambalés Grand & Cauterets & 2342 & 42.4924 & -0.1407 & 13994.22 \\
\hline 180 & 2001 & Pond Opale & Cauterets & 2222 & 42.4923 & -0.1323 & 175.93 \\
\hline 181 & 2001 & Pond Opale 1 & Cauterets & 2248 & 42.4923 & -0.1323 & 54.98 \\
\hline 182 & 2001 & Pond Opale 2 & Cauterets & 2260 & 42.4923 & -0.1323 & 1412.15 \\
\hline 184 & $2001(183 / 2000)$ & Lake Opale Petit Inférieur & Cauterets & 2287 & 42.4923 & -0.1323 & 8466.59 \\
\hline 186 & $2001(185 / 2000)$ & Lake Opale Supérieur & Cauterets & 2320 & 42.4923 & -0.1323 & 32842.99 \\
\hline 187 & 2001 & Pond Petit Laquet & Cauterets & 2360 & 42.4923 & -0.1323 & 169.65 \\
\hline 188 & 2001 & Lake Petit Laquet & Cauterets & 2350 & 42.4923 & -0.1323 & 3765.98 \\
\hline 189 & 2001 & Lake Costalade Supérieur & Cauterets & 2320 & 42.4923 & -0.1323 & 9519.03 \\
\hline 190 & 2001 & Pond Cambalés & Cauterets & 2315 & 42.4923 & -0.1323 & 829.38 \\
\hline 191 & 2001 & Lake Costalade Inférieur & Cauterets & 2310 & 42.4923 & -0.1323 & 10148.92 \\
\hline 203 & 2002 & Lake Pourtet & Cauterets & 2420 & 42.5026 & -0.1236 & 80311.96 \\
\hline 205 & 2002 & Lake Pourtet 2 & Cauterets & 2307 & 42.5025 & -0.1152 & 1374.45 \\
\hline 207 & $2002(206 / 2000)$ & Lake Embarrat 2 & Cauterets & 2139 & 42.5025 & -0.1152 & 14278.54 \\
\hline 208 & 2002 & Lake Embarrat 1 & Cauterets & 2078 & 42.5024 & -0.1108 & 35215.68 \\
\hline 209 & 2001 & Lake De la Badéte & Cauterets & 2344 & 42.5024 & -0.1108 & 58109.25 \\
\hline 210 & 2001 & Lake Col d'Arratille & Cauterets & 2501 & 42.4709 & -0.1033 & 2670.28 \\
\hline 211 & 2001 & Pond Arratille 1 & Cauterets & 2363 & 42.4741 & -0.1031 & 141.37 \\
\hline 212 & 2001 & Pond Arratille 2 & Cauterets & 2330 & 42.4741 & -0.1031 & 63.62 \\
\hline 213 & 2001 & Pond Arratille 3 & Cauterets & 2315 & 42.4741 & -0.1031 & 3691.37 \\
\hline 214 & 2001 & Pond Arratille 4 & Cauterets & 2289 & 42.4741 & -0.1031 & 31.42 \\
\hline 215 & 2001 & Pond Arratille 5 & Cauterets & 2315 & 42.4741 & -0.1031 & 731.21 \\
\hline 216 & 2001 & Pond Arratille 6 & Cauterets & 2268 & 42.4741 & -0.1031 & 1165.53 \\
\hline 217 & 2001 & Lake Arratille & Cauterets & 2247 & 42.4741 & -0.1031 & 70038.67 \\
\hline 222 & 2002 & Lake Chabarrou Supérieur & Cauterets & 2422 & 42.4813 & -0.0946 & 1406.02 \\
\hline 224 & 2002 & Lake Chabarrou & Cauterets & 2302 & 42.4812 & -0.0902 & 34150.98 \\
\hline 225 & 2002 & Lake Chabarrou Inférieur & Cauterets & 2390 & 42.4812 & -0.0902 & 617.93 \\
\hline 226 & 2002 & Pond Chabarrou 1 & Cauterets & 2364 & 42.4812 & -0.0902 & 412.33 \\
\hline 229 & 2002 & Pond Chabarrou 4 & Cauterets & 2364 & 42.4812 & -0.0902 & 14.01 \\
\hline 231 & 2001 & Oulettes. glacier runoff & Cauterets & 2151 & 42.4707 & -0.0905 & 2434.66 \\
\hline 232 & 2001 & Pond Arraillé Inférieur & Cauterets & 2441 & 42.4706 & -0.0821 & 714.71 \\
\hline 233 & 2001 & Lake Arraillé Milieu & Cauterets & 2450 & 42.4706 & -0.0821 & 2544.69 \\
\hline 235 & 2002 & Lake Estibe Aute 1 & Cauterets & 2515 & 42.4737 & -0.0736 & 12935.51 \\
\hline 237 & 2002 & Lake Estibe Aute 3 & Cauterets & 2515 & 42.4737 & -0.0736 & 24864.92 \\
\hline 241 & 2001 & Pond Montferrat & Luz & 2207 & 42.4455 & -0.0743 & 109.96 \\
\hline 242 & 2001 & Lake Montferrat & Luz & 2374 & 42.4455 & -0.0743 & 10445.80 \\
\hline 243 & 2001 & Pond Montferrat 1 & Luz & 2372 & 42.4455 & -0.0743 & 1313.19 \\
\hline 244 & 2001 & Pond Montferrat 2 & Luz & 2440 & 42.4455 & -0.0743 & 1011.59 \\
\hline 245 & 2001 & Lake Montferrat 1 & Luz & 2438 & 42.4455 & -0.0743 & 2111.15 \\
\hline 246 & 2001 & Lake Montferrat 3 & Luz & 2438 & 42.4455 & -0.0743 & 302.38 \\
\hline 247 & 2001 & Lake Montferrat 4 & Luz & 2437 & 42.4455 & -0.0743 & 319.66 \\
\hline 249 & 2001 & Lake Montferrat 6 & Luz & 2440 & 42.4455 & -0.0743 & 500.30 \\
\hline 255 & 2002 & Lake Estibe Aute Inférieur & Cauterets & 2324 & 42.4842 & -0.0733 & 45356.74 \\
\hline 256 & 2002 & Pond Estibe Aute Supérieur & Cauterets & 2324 & 42.4842 & -0.0733 & 614.97 \\
\hline 259 & 2002 & Lake Estibe Aute Supérieur & Cauterets & 2328 & 42.4842 & -0.0733 & 125663.71 \\
\hline 261 & 2002 & Pond Estibe Aute Supérieur 1 & Cauterets & 2331 & 42.4842 & -0.0733 & 435.90 \\
\hline 263 & 2001 & Lake Estom & Cauterets & 1804 & 42.4808 & -0.065 & 67122.71 \\
\hline
\end{tabular}




\begin{tabular}{|c|c|c|c|c|c|c|c|}
\hline 264 & $2001(265 / 2002)$ & Pond Sentier d'Estom 1 & Cauterets & 2235 & 42.4703 & -0.0653 & 320.44 \\
\hline 266 & $2001(267 / 2002)$ & Pond Sentier d'Estom 2 & Cauterets & 2240 & 42.4703 & -0.0653 & 247.39 \\
\hline 268 & $2001(269 / 2002)$ & Pond Sentier d'Estom 3 & Cauterets & 2240 & 42.4703 & -0.0653 & 243.47 \\
\hline 270 & $2001(271 / 2002)$ & Pond Sentier d'Estom 4 & Cauterets & 2248 & 42.4703 & -0.0653 & 388.76 \\
\hline 2 & $2001(273 / 2002)$ & Lake Labas & Cauterets & 2281 & 42.4702 & -0.0609 & 49542.92 \\
\hline 74 & $2001(275 / 2002)$ & Lake Oulettes d'Estom & Cauterets & 2360 & 42.4702 & -0.0609 & 95504.42 \\
\hline 6 & $2001(277 / 2002)$ & Lake Couy & Cauterets & 2445 & 42.4702 & -0.0609 & 92909.86 \\
\hline 78 & $2001(279 / 2002$ & Lake Turon Couy & Cauterets & 2485 & 42.463 & -0.0611 & 4712.39 \\
\hline 281 & $2001(282 / 2002)$ & Pond Turon Couy 2 & Cauterets & 2492 & 42.463 & -0.0611 & 471.24 \\
\hline 283 & $2001(284 / 2002)$ & Lake Couy Supérieur & Cauterets & 2500 & 42.463 & -0.0611 & 4712.39 \\
\hline 285 & $2001(286 / 2002)$ & Pond Couy Supérieur & Cauterets & 2500 & 42.463 & -0.0611 & 4712.25 \\
\hline 88 & $2002(287 / 2001)$ & Lake Glace & Cauterets & 2678 & 42.463 & -0.0611 & 136030.96 \\
\hline 9 & 2002 & Lake Petit Lac Du Col & Cauterets & 2650 & 42.463 & -0.0611 & 21650.29 \\
\hline 1 & 2001 & *Lake Ossoue & Luz & 1834 & 42.4525 & -0.0614 & 38954.60 \\
\hline 92 & 2002 & Lake Cardal & Luz & 2221 & 42.4348 & -0.0618 & 4618.14 \\
\hline 293 & 2002 & Pond Col de la Bernatoire & Luz & 2045 & 42.4348 & -0.0618 & 144.51 \\
\hline 94 & 2002 & Pond Col de la Bernatoire 1 & Luz & 2393 & 42.4316 & -0.062 & 3166.73 \\
\hline 295 & 2001 & Lake Especiérès & Luz & 2195 & 42.424 & -0.0409 & 27876.89 \\
\hline 296 & 2001 & Lake Especiérès Infèrieur & Luz & 2186 & 42.424 & -0.0409 & 1658.71 \\
\hline 97 & 2001 & Pond Plaiteau de Saint André & Luz & 2075 & 42.4239 & -0.0326 & 94.25 \\
\hline 8 & 2001 & Ponds Labas Blanc & Luz & 2009 & 42.4239 & -0.0326 & 989.60 \\
\hline 300 & 2002 & Laquet de Bassia & Luz & 2275 & 42.4613 & 0.0448 & 22855.09 \\
\hline 301 & 2001 & Pond Bassia 1 & Luz & 2277 & 42.4613 & 0.0448 & 967.61 \\
\hline 302 & 2002 & Pond Bassia 2 & Luz & 2275 & 42.4613 & 0.0448 & 3104.68 \\
\hline 303 & 2002 & Pond Le Cot 1 & Luz & 2063 & 42.4402 & 0.0525 & 125.66 \\
\hline 304 & 2002 & Pond Le Cot 2 & Luz & 2130 & 42.4402 & 0.0525 & 673.87 \\
\hline 305 & 2002 & Pond Le Cot 3 & Luz & 2130 & 42.4402 & 0.0525 & 824.67 \\
\hline 306 & 2002 & Pond Le Cot 4 & Luz & 2130 & 42.4402 & 0.0525 & 353.43 \\
\hline 307 & 2001 & Pond Serre Longue & Luz & 2190 & 42.433 & 0.0523 & 537.21 \\
\hline 308 & 2001 & Pond Esbarris & Luz & 2139 & 42.4329 & 0.0607 & 694.29 \\
\hline 309 & 2001 & Lake Aires Supérieur & Luz & 2089 & 42.4329 & 0.0607 & 14953.98 \\
\hline 310 & 2001 & Lake Aires Inférieur 1 & Luz & 2081 & 42.4329 & 0.0607 & 1865.32 \\
\hline 311 & 2001 & Lake Aires Inférieur 2 & Luz & 2081 & 42.4329 & 0.0607 & 7314.41 \\
\hline 312 & 2001 & Lake Comble 2 & Luz & 2099 & 42.4327 & 0.0651 & 3758.13 \\
\hline 313 & 2001 & Lake Comble 1 & Luz & 2098 & 42.4327 & 0.0651 & 6660.18 \\
\hline 14 & 2001 & Lake Troumouse 1 & Luz & 2098 & 42.4329 & 0.0607 & 433.54 \\
\hline 15 & 2001 & Pond Troumouse 1 & Luz & 2105 & 42.4329 & 0.0607 & 11.78 \\
\hline 16 & 2001 & Pond Troumouse 2 & Luz & 2102 & 42.4329 & 0.0607 & 9.42 \\
\hline 317 & 2001 & Pond Troumouse 3 & Luz & 2133 & 42.4329 & 0.0607 & 25.13 \\
\hline 318 & 2001 & Lake Troumouse 2 & Luz & 2135 & 42.4329 & 0.0607 & 687.22 \\
\hline 319 & 2001 & Lake Troumouse 3 & Luz & 2145 & 42.4329 & 0.0607 & 5006.91 \\
\hline 320 & 2001 & Lake Troumouse 4 & Luz & 2148 & 42.4329 & 0.0607 & 1209.51 \\
\hline 322 & 2002 & Lake Rabiet & Luz & 2191 & 42.4927 & 0.0457 & 13469.58 \\
\hline 324 & 2002 & Lake Bugarret & Luz & 2281 & 42.4853 & 0.054 & 86079.64 \\
\hline 325 & 2002 & Lake Glere & Luz & 2103 & 42.5103 & 0.0546 & 41563.27 \\
\hline 329 & 2002 & Lake Det Mail & Luz & 2350 & 42.5101 & 0.0623 & 65426.81 \\
\hline 330 & 2002 & Lake Oueil Nègre & Luz & 2349 & 42.5031 & 0.0544 & 753.98 \\
\hline 337 & 2002 & Lake Estelat Supérieur & Luz & 2423 & 42.4958 & 0.0543 & 34086.28 \\
\hline 338 & 2002 & Lake Glacé de Maniportet & Luz & 2747 & 42.4926 & 0.0541 & 12126.03 \\
\hline 340 & 2002 & Lake Bleu De Maniportet & Luz & 2651 & 42.4958 & 0.0543 & 26295.13 \\
\hline 345 & 2002 & Lake Vert Maniportet Long & Luz & 2632 & 42.4957 & 0.0627 & 6408.85 \\
\hline 347 & 2002 & Pond Vert Maniportet Rond & Luz & 2628 & 42.4957 & 0.0627 & 6872.23 \\
\hline 351 & 2002 & Lake Breche 2 & Luz & 2433 & 42.4957 & 0.0627 & 2209.33 \\
\hline 352 & 2002 & Lake Breche 1 & Luz & 2409 & 42.4957 & 0.0627 & 1845.69 \\
\hline 354 & 2001 & Pond Aguilous 1 & Luz & 2240 & 42.4506 & 0.0612 & 141.37 \\
\hline$\sigma \theta$ & 2001 & Pond Agulious 2 & Luz & 2255 & 42.4506 & 0.0612 & 268.61 \\
\hline
\end{tabular}




\begin{tabular}{llllllll}
357 & 2002 & Pond Cap de Long 2 & Aure & 2591 & 42.4819 & 0.0706 & 1969.78 \\
364 & 2001 & Pond Barroude 6 & Aure & 2345 & 42.4326 & 0.0735 & 400.55 \\
365 & 2001 & Pond Barroude 5 & Aure & 2350 & 42.4326 & 0.0735 & 1157.68 \\
366 & 2001 & Pond Barroude 4 & Aure & 2356 & 42.4326 & 0.0735 & 1762.43 \\
367 & 2001 & Pond Barroude 3 & Aure & 2374 & 42.4326 & 0.0735 & 668.37 \\
368 & 2001 & Pond Barroude 2 & Aure & 2375 & 42.4326 & 0.0735 & 186.92 \\
369 & 2001 & Pond Barroude 1 & Aure & 2376 & 42.4325 & 0.0819 & 803.46 \\
372 & 2001 & Lake Barroude Grand & Aure & 2355 & 42.4325 & 0.0819 & 53603.42 \\
373 & 2001 & Lake Barroude Petit & Aure & 2377 & 42.4325 & 0.0819 & 62682.63 \\
\hline
\end{tabular}

Table S2. Variables (and their measurement units) collected from the 189 lakes and ponds of the central region of the Pyrenees National Park (France) at different scales. Superscripts represent ${ }^{a}$ numerical, ${ }^{b}$ categorical and cnominal variables.

\begin{tabular}{|c|c|c|}
\hline \multicolumn{3}{|c|}{ Variable type } \\
\hline${ }^{\mathrm{a}}$ Riparian vegetation & ${ }^{\mathrm{c}}$ Catchment type & ${ }^{\mathrm{a}}$ Longitude \\
\hline Species presence & $\begin{array}{l}\text { Plain, U - shape valley, slope, mountain pass, V - } \\
\text { shape valley, head of glacial valley }\end{array}$ & Geographic degrees \\
\hline${ }^{\mathrm{a}}$ Lake sediment $\mathrm{C}, \mathrm{N}, \mathrm{Na}, \mathrm{Mg}, \mathrm{Al}$, & ${ }^{\mathrm{c}}$ Main geology & ${ }^{\mathrm{a}}$ Latitude \\
\hline $\begin{array}{l}\mathbf{S i}, \mathbf{P}, \mathbf{S}, \mathbf{C l}, \mathbf{K}, \mathbf{C a}, \mathbf{T i} \text {, and } \mathbf{F e} \\
\% \text { mass-mass }\end{array}$ & $\begin{array}{l}\text { Conglomerate-sandstone-claystone, limestone } \\
\text { (+sandstone-marlstone-schist enclaves), schist }\end{array}$ & Geographic degrees \\
\hline${ }^{\mathrm{a}}$ Lake sediment $\mathrm{V}, \mathrm{Cr}, \mathrm{Mn}, \mathrm{Co}$, & $\begin{array}{l}\text { (+andesite-sandstone-claystone and granite- } \\
\text { limestone), granite (+schist) }\end{array}$ & $\begin{array}{l}{ }^{\mathrm{a}} \text { Altitude } \\
\text { Meters above sea level }\end{array}$ \\
\hline $\mathrm{Ni}, \mathrm{Cu}, \mathrm{Zn}, \mathrm{As}, \mathrm{Rb}, \mathrm{Sr}, \mathrm{Ba}$ and $\mathrm{Pb}$ & ${ }^{\mathrm{b}}$ Snow deposits in the catchment & \\
\hline $\mathrm{mg} \mathrm{kg}^{-1}$ & $\begin{array}{l}\text { Absent, very scarce, scarce, abundant, very } \\
\text { abundant }\end{array}$ & \\
\hline${ }^{\mathrm{a}}$ Lake water $\mathbf{p H}$ & ${ }^{\mathrm{c}}$ Visible connectivity with other lake & \\
\hline (surface and bottom) & $\begin{array}{l}\text { Absent, surrounded by another lake, with another } \\
\text { one, in chain }\end{array}$ & \\
\hline${ }^{\mathrm{a}}$ Lake water conductivity & ${ }^{\mathrm{c}}$ Nature of tributary & \\
\hline (surface and bottom) & Meteoric, spring, stream/waterfall & \\
\hline$\mu \mathrm{S} \mathrm{cm}^{-1}$ & ${ }^{\mathrm{b}}$ Tributary discharge & \\
\hline${ }^{\mathrm{a}}$ Lake water $\mathrm{Li}, \mathrm{B}, \mathrm{Na}, \mathrm{Mg}, \mathrm{Al}, \mathrm{K}$, & $\begin{array}{l}\text { Absent, low discharge, medium discharge, high } \\
\text { discharge }\end{array}$ & \\
\hline $\mathrm{Ca}, \mathrm{Mn}, \mathrm{Fe}, \mathrm{Ni}, \mathrm{Cu}, \mathrm{Ga}, \mathrm{Se}, \mathrm{Sr}$ & ${ }^{\mathrm{c}}$ Nature of water output & \\
\hline $\begin{array}{l}\text { Ba, } \mathbf{R b} \text { and } \mathbf{P b} \\
\mathrm{mg} \mathrm{L}^{-1}\end{array}$ & $\begin{array}{l}\text { Absent, temporary, surface-small, surface-medium, } \\
\text { surface-large, subterranean, dam output } \\
\text { b } \% \text { grass covered slopes }\end{array}$ & \\
\hline & $<10,11-20,21-30,31-40,41-50,51-60,61-70,71-$ & \\
\hline & $80,81-90,91-100$ & \\
\hline & ${ }^{\mathrm{b}}$ Slope of lake perimeter & \\
\hline & $\begin{array}{l}\text { Plain, plain in alternation with medium slopes, } \\
\text { medium slopes, steep in alternation with }\end{array}$ & \\
\hline & medium/plain, steep in $>50 \%$ of perimeter & \\
\hline & ${ }^{\mathrm{b}}$ Lake size & \\
\hline & Pool $\left(<315 \pm 333 \mathrm{~m}^{2}\right)$, pond $\left(1566 \pm 1985 \mathrm{~m}^{2}\right)$, small & \\
\hline
\end{tabular}


lake $\left(9157 \pm 10267 \mathrm{~m}^{2}\right)$, medium size lake

$\left(41127 \pm 31820 \mathrm{~m}^{2}\right)$, large lake $\left(91441 \pm 37307 \mathrm{~m}^{2}\right)$

${ }^{\mathrm{b}}$ Lake fractal development order

$1,2,3,4$

${ }^{\mathrm{b}}$ Shore snow coverage

Absent, $<10 \%, 11-50 \%,>51 \%$, into the water

${ }^{\mathrm{b}} \%$ grass covered shore

$<10,11-20,21-30,31-40,41-50,51-60,61-70,71-$

$80,81-90,91-100$

${ }^{\mathrm{b}}$ Aquatic vegetation

Absent, absent but water flooding the grassland, scarce, abundant

List S1. The taxonomical composition of riparian vegetation in the 189 central Pyrenean lakes and ponds surveyed for this study.

\begin{tabular}{|c|c|c|c|}
\hline Aconitum spp. & Cryptogramma crispa & Luzula desvauxii & Rhinanthus minor \\
\hline Adenostyles alliariae & Deschampsia cespitosa & Luzula luzuloides & Rhododendron ferrugineum \\
\hline Agrostis capillaris & Dethawia tenuifolia & Luzula nutans & Rumex alpinus \\
\hline Alchemilla alpina & Doronicum austriacum & Luzula sudetica & Rumex crispus \\
\hline Alchemilla vulgaris & Draba aizoides & Lychnis alpina & Rumex scutatus \\
\hline Allium schoenoprasum & Empetrum nigrum & Menyanthes trifoliata & Sagina procumbens \\
\hline Androsace carnea & Epilobium alsinifolium etc & Merendera pyrenaica & Salix herbacea \\
\hline Antennaria dioica & Equisetum variegatum & Meum athamanticum & Salix reticulata \\
\hline Anthoxanthum odoratum & Ericasp. & Minuartia sedoides & Sanguisorba officinalis \\
\hline Anthyllis vulneraria & Eriophorum latifolium & Molinia caerulea & Saxifraga aizoides \\
\hline Armeria alliacea & Euphrasiasp. & Myosotis alpina & Saxifraga oppositifolia \\
\hline Armeria maritima alpina & Festuca eskia & Myosotis scorpioides & Saxifraga stellaris \\
\hline Arnica montana & Fontinalis antipyretica & Nardus stricta & Sedum album \\
\hline Bartsia alpina & Galium pyrenaicum & Nigritella nigra & Selaginella selaginoides \\
\hline Bellis perennis & Galium verum & Oxyria digyna & Sempervivum arachnoideum \\
\hline Betula pendula & Gentiana acaulis & Oxytropis campestris & Sempervivum montanum \\
\hline Botrychium lunaria & Gentiana lutea & Oxytropis pyrenaica & Sesamoides pygmaea \\
\hline Callitriche palustris & Gentiana verna & Parnassia palustris & Sibbaldia procumbens \\
\hline Calluna vulgaris & Geranium cinereum & Pedicularis mixta & Silene acaulis \\
\hline Caltha palustris & Geranium sylvaticum & Phleum alpinum & Soldanella alpina \\
\hline Campanula rotundifolia & Geum montanum & Phyteuma orbiculare & Sorbus aucuparia \\
\hline Cardamine raphanifolia & Globularia repens & Pinguicula grandiflora & Sparganium angustifolium \\
\hline Carduus carlinoides & Glyceria fluitans & Pinguicula vulgaris & Sphagnum sp. \\
\hline Carex atrata & Gnaphalium supinum & Plantago alpina & Succisa pratensis \\
\hline Carex brachystachys & Gnaphalium sylvaticum & Plantago lanceolata & Swertia perennis \\
\hline Carex caryophyllea & Hieracium pilosella & Plantago media & Taraxacum sp. \\
\hline Carex curvula & Homogyne alpina & Роа аппиа & Thalictrum alpinum \\
\hline Carex demissa & Huperzia selago & Polygala alpina & Thesium alpinum \\
\hline Carex echinata & Hutchinsia alpina & Polygonum viviparum & Thymus serpyllum \\
\hline Carex flacca & Hypericum montanum & Potentilla anserina & Trichophorum cespitosum \\
\hline Carex flava & Jasione montana & Potentilla erecta & Trifolium alpinum \\
\hline
\end{tabular}


DOI (Science of the Total Environment 2017): http://dx.doi.org/10.1016/j.scitotenv.2017.05.135

\begin{tabular}{|c|c|c|c|}
\hline Carex frigida & Juncus articulatus & Primula farinosa & Trifolium repens \\
\hline Carex hallerana & Juncus filiformis & Primula integrifolia & Vaccinium myrtillus \\
\hline Carex macrostylon & Juncus inflexus & Primula viscosa & Vaccinium uliginosum \\
\hline Carex nigra & Juniperus communis ssp. nana & Prunella vulgaris & Veratrum album \\
\hline Carex pulicaris & Kobresia myosuroides & Pulsatilla sp. & Veronica alpina \\
\hline Carex riparia & Kobresia simpliciuscula & Ranunculus alpestris & Veronica beccabunga \\
\hline Carex rostrata & Leontodon autumnalis & Ranunculus aquatilis & Veronica fruticans \\
\hline Carex sempervirens & Leontopodium alpinum & Ranunculus pyrenaeus & Veronica nummularia \\
\hline Carum carvi & Leucanthemopsis alpina & Ranunculus repens & Veronica officinalis \\
\hline Chara foetida & Linaria alpina & Ranunculus reptans & Viola biflora \\
\hline Chenopodium bonus-henricus & Lotus alpinus & Rhamnus pumilus & Viola palustris \\
\hline Cochlearia officinalis & Luzula alpinopilosa & & \\
\hline
\end{tabular}

$\mathrm{N}$ (number of species) $=168$. 